NBER WORKING PAPER SERIES

\title{
BANKRUPTCY SPILLOVERS
}

\author{
Shai Bernstein \\ Emanuele Colonnelli \\ Xavier Giroud \\ Benjamin Iverson \\ Working Paper 23162 \\ http://www.nber.org/papers/w23162 \\ NATIONAL BUREAU OF ECONOMIC RESEARCH \\ 1050 Massachusetts Avenue \\ Cambridge, MA 02138 \\ February 2017
}

We are grateful to Effi Benmelech, Jess Cornaggia, Song Ma, Enrico Moretti, Holger Mueller, Charles Nathanson, Josh Rauh, Amit Seru, as well as seminar participants at Stanford, NYU, Penn State University, University of Toronto, the 2017 Jackson Hole Finance Conference, and the Yale Junior Finance Faculty Conference for helpful comments and suggestions. Any opinions and conclusions expressed herein are those of the authors and do not necessarily represent the views of the U.S. Census Bureau or the National Bureau of Economic Research. All results have been reviewed to ensure that no confidential information is disclosed.

NBER working papers are circulated for discussion and comment purposes. They have not been peer-reviewed or been subject to the review by the NBER Board of Directors that accompanies official NBER publications.

(C) 2017 by Shai Bernstein, Emanuele Colonnelli, Xavier Giroud, and Benjamin Iverson. All rights reserved. Short sections of text, not to exceed two paragraphs, may be quoted without explicit permission provided that full credit, including $\odot$ notice, is given to the source. 
Bankruptcy Spillovers

Shai Bernstein, Emanuele Colonnelli, Xavier Giroud, and Benjamin Iverson

NBER Working Paper No. 23162

February 2017

JEL No. G33,R12

\begin{abstract}
How do different bankruptcy approaches affect the local economy? Using U.S. Census microdata at the establishment level, we explore the spillover effects of reorganization and liquidation on geographically proximate firms. We exploit the random assignment of bankruptcy judges as a source of exogenous variation in the probability of liquidation. We find that within a five-year period, employment declines substantially in the immediate neighborhood of the liquidated establishments, relative to reorganized establishments. Most of the decline is due to lower growth of existing establishments and, to a lesser extent, reduced entry into the area. The spillover effects are highly localized and concentrate in the non-tradable and service sectors, particularly when the bankrupt firm operates in the same sector. These results suggest that liquidation leads to a reduction in consumer traffic to the local area and to a decline in knowledge spillovers between firms. The evidence is inconsistent with the notion that liquidation leads to creative destruction, as the removal of bankrupt businesses does not lead to increased entry nor the revitalization of the area.
\end{abstract}

Shai Bernstein

Stanford Graduate School of Business 655 Knight Way

Stanford, CA 94305

and NBER

shaib@stanford.edu

Emanuele Colonnelli

Stanford University

Department of Economics

579 Serra Mall

Stanford, CA 94305

e.colonnelli@gmail.com
Xavier Giroud

MIT Sloan School of Management

100 Main Street, E62-639

Cambridge, MA 02142

and NBER

xgiroud@mit.edu

Benjamin Iverson

Northwestern University

2001 Sheridan Road

Evanston, IL 60208

b-iverson@kellogg.northwestern.edu 


\section{Introduction}

Bankruptcy institutions play a significant role in resolving insolvency and financial distress in the economy. Since 1980, more than 1.8 million businesses have filed for bankruptcy in the U.S. Most of these cases are resolved through either reorganization (Chapter 11 under the U.S. Bankruptcy code), that attempts to rehabilitate the distressed firm, or liquidation (Chapter 7 under the U.S. Bankruptcy code), in which the firm ceases to exist and all assets are auctioned. Given their importance, bankruptcy institutions have spurred a large literature that mostly focused on how these two regimes affect the bankrupt firms and their claim holders. ${ }^{1}$ Yet, bankruptcy institutions may have far-reaching implications on other economically related firms that are not represented in courts. In this paper, we explore the spillover effects these two bankruptcy regimes, liquidation and reorganization, may impose on the local economy.

In theory, the impact of liquidation - relative to reorganization - on the local economy is ambiguous. The agglomeration literature highlights the importance of complementarities that arise between geographically proximate firms (for recent surveys, see Duranton and Puga (2004); Glaeser and Gottlieb (2009); Moretti (2010)). If agglomeration matters-i.e., if spatial concentration of economic activity benefits firms within the agglomeration-liquidation might disrupt agglomeration economies and therefore hurt neighboring firms. In this case, reorganization may lead to a more desirable outcome, as firms are allowed to restructure, continue their operations, and preserve existing agglomeration linkages.

On the other hand, liquidation could benefit the local economy. In particular, if inefficient companies are liquidated, their assets (such as buildings, capital, and labor) can be absorbed by the local economy and redeployed toward more productive uses, attracting new entrants to the area, enhancing synergies with neighboring firms, and contributing to the revitalization of the neighborhood. In other words, liquidation can initiate a "creative destruction" process in which inefficient assets are replaced by more efficient ones. ${ }^{2}$ On the other hand, reorganization may permit

\footnotetext{
${ }^{1}$ See, e.g., Baird (1986, 1993); Aghion et al. (1992); Hart (2000).

${ }^{2}$ Creative destruction is the driving mechanism in the "cleansing theories" of recessions (e.g., Caballero and Hammour $(1994,1996))$, according to which the process of liquidation and reallocation of production factors is a main function of recessions. As Schumpeter (1934) states it, "depressions are not simply evils, which we might attempt to suppress, but forms of something which has to be done, namely, adjustment to change" (p. 16).
} 
the continuation of inefficient firms due to conflicts of interest and agency problems among claim holders (e.g., Bebchuk (1988); Gertner and Scharfstein (1991)). This may prevent the reallocation of assets to better uses, limiting potential synergies with local firms and the revitalization of the area.

Ultimately, whether these two bankruptcy procedures create positive or negative spillovers is an empirical question. However, estimating these spillover effects is challenging. First, many companies have multiple establishments, which makes it difficult to determine the relevant local area and identify all establishments that are potentially affected by the bankrupt firm. Second, the decision to liquidate versus reorganize is not random. The primary concern is that liquidation is likely more prevalent in declining areas. Hence, finding an association between liquidation and a subsequent decline in economic activity could be spurious, merely reflecting a negative trend at the local level.

To overcome the first obstacle, we use detailed micro data at the establishment level from the U.S. Census Bureau. Specifically, we combine the Longitudinal Business Database (LBD) with bankruptcy filings from LexisNexis Law to obtain a comprehensive dataset of 91,000 establishments belonging to bankrupt firms. Using the geo-codes from the LBD, we determine the relevant local area for each bankrupt establishment and then study how bankruptcy affects other establishments at the same location. ${ }^{3}$

To overcome the second obstacle - the endogeneity of the decision to liquidate versus reorganize - we employ an instrumental variable (IV) approach that exploits the fact that U.S. bankruptcy courts use a blind rotation system to assign cases to judges, effectively randomizing filers to judges within each court division. The assignment of bankruptcy judges is therefore orthogonal to the filer's characteristics and, importantly, to the local economic conditions in the vicinity of the filer's establishments. Judges differ in their propensity to force the liquidation of companies by pushing them to Chapter 7, as opposed to allowing them to reorganize in Chapter 11. The random allocation of filers to bankruptcy judges thus results in the assignment of similar companies to judges who differ in their propensity to treat the firms with different bankruptcy procedures. We exploit

\footnotetext{
${ }^{3}$ Using Census data allows us to consider all industries. This is in sharp contrast to most of the literature on agglomeration that examines the manufacturing sector only. Manufacturing is found disproportionately in small- and medium-size cities, as well as the rural fringes of cities (Kolko (2000)). Hence, exploring the entire population of bankrupt firms allows us to explore relations across all industries and all geographies, including larger and denser cities.
} 
this heterogeneity among judges to instrument for the probability that a given company is liquidated. This, in turn, allows us to disentangle the effect of liquidation from potential confounds such as changes in local economic conditions. In essence, this identification strategy is closest to the ideal experiment in which otherwise identical companies are randomly assigned to liquidation or reorganization. ${ }^{4}$

Using this empirical approach, we find that the liquidation of an establishment imposes negative spillovers on the immediate neighborhood (as captured by Census blocks). Specifically, relative to reorganized establishments, we find that liquidation leads to an average decrease in employment of $4 \%$ per year among non-bankrupt businesses in the same Census block. This estimate corresponds to a multiplier of 1.3 , that is, for every job that is lost at the liquidated establishment, another 1.3 jobs are lost due to spillovers. The effect takes place gradually and persists over the five-year period after the bankruptcy filing. We further decompose this effect into changes at existing establishments and entry into the area. We find that most of the decline in employment is due to lower growth of existing establishments and, to a lesser extent, reduced entry into the area.

Overall, these results indicate that liquidation adversely affects the local economy through spillovers. As such, our results are inconsistent with the creative destruction argument, which posits that forcing the liquidation of distressed firms will help revitalize the local area and induce entry by freeing up resources for healthy firms to use. Under creative destruction, we would expect higher employment following liquidation, or at least higher entry into the area. Yet, neither is supported by the data.

Interestingly, we find that the spillover effects are highly localized. The effects are strongest at the Census block level, and decay for larger geographical areas (Census block groups and Census tracts). This is consistent with prior evidence on the localized nature of agglomeration spillovers (Rosenthal and Strange (2003); Arzaghi and Henderson (2008)).

We also explore how the spillover effects differ depending on the "fate" of the bankrupt establishment, that is, whether it continued operations, remained vacant, or was reallocated to a different user. Consistent with the notion that liquidation leads to a disruption of existing agglom-

\footnotetext{
${ }^{4}$ This approach follows the growing literature that takes advantage of the random assignment of judges and heterogeneity in judges' interpretation of the law (e.g., Kling (2006); Doyle (2008); Chang and Schoar (2013); Dobbie and Song (2015); Galasso and Schankerman (2015); Bernstein et al. (2016)).
} 
eration linkages, we find that the negative spillovers on local employment are larger if the bankrupt establishment stays vacant or is redeployed to a different industry, while they are smaller if the establishment remains with its current user or remains in the same industry.

Finally, we examine three mechanisms through which liquidation may spill over to neighboring firms. First, liquidation may reduce customer traffic to the area. This will cause negative spillovers on nearby stores if those stores relied on these customers for their own demand (Pashigian and Gould (1998), Gould et al. (2005), Benmelech et al. (2014)). ${ }^{5}$ In the second mechanism, liquidation may reduce business synergies between proximate firms. As highlighted by prior literature, such synergies may arise through the reduction of production costs pertaining to three key factors: goods, knowledge, and workers (Moretti (2011), Glaeser and Gottlieb (2009), and Duranton and Puga (2004)). Specifically, by locating near firms in similar industries, businesses can reduce transportation costs of goods and services, increase the flow of ideas and skills between firms, and create thick labor markets to better match workers and firms. By forcing the removal of a business from a locally agglomerated market, liquidation may disrupt these synergies. Finally, in the third mechanism, it might be the case that the liquidation of an establishment simply reduces local demand for goods and services, as the employees of that establishment either lose their jobs or relocate to other areas (Moretti (2010)).

To examine these potential mechanisms, we decompose our sample into three broad industry sectors: 1) the non-tradable sector (e.g., restaurants and retail), which relies on local demand and customer flow to the area, 2) the tradable sector (e.g., manufacturing), which is likely to rely on nonlocal demand, and 3) services (e.g., law firms, health services, and advertisement agencies, among others). Consistent with the customer traffic channel, we find that the liquidation of non-tradable establishments adversely affects neighboring non-tradable establishments, while the liquidation of tradable or services establishments does not. This result suggests that liquidation affects establishments that rely on local demand by reducing customer traffic to the local area. Moreover, we also find that the liquidation of services establishments adversely affects neighboring services establishments, which is consistent with the knowledge spillover and information sharing channel.

\footnotetext{
${ }^{5}$ Liquidated stores may further deter customers if establishments are vacant and neglected. Indeed, evidence from residential real estate shows that vacancy leads to poor maintenance and increased crime (Campbell et al. (2011); Ellen et al. (2013); Cui and Walsh (2015)). Arguably, the same may apply to commercial real estate.
} 
In contrast, our evidence is inconsistent with other spillover mechanisms. In particular, we find no evidence that tradable liquidations affect non-tradable employment, which is inconsistent with the employee demand channel. We also find that tradable employment is unaffected by liquidation in any sector, which is consistent with the notion that these businesses rely on non-local demand, and therefore may be least affected by geographically proximate liquidations. Finally, the fact that the liquidation spillovers we identify are highly localized is inconsistent with the transportation cost and labor market pooling channels, as these mechanisms likely function in areas larger than a Census block.

These results further show that liquidation is not always detrimental to the area. In particular, the non-result in the tradable sector indicates that liquidation only hurts the surroundings if the liquidated establihsment's operations are tied to the local environment. This finding echoes well with the agglomeration literature. As Moretti (2011) emphasize in his review (p. 1278): "[t]heory suggests that the local multiplier for the tradable sector should be smaller than the one for the nontradable sector, and possibly even negative. Consistent with this hypothesis, Carrington (1996), Moretti (2010), and Black et al. (2005) fail to find any significant effect of employment in the tradable sector."

Our paper contributes to several strands of the literature. First, several articles examine the costs and benefits of reorganization procedures such as Chapter 11 (e.g., Baird (1986); Aghion et al. (1992); Bradley and Rosenzweig (1992); Hotchkiss (1995); Gilson (1997); Bris et al. (2006)), while others consider frictions that may exist in distressed liquidations (e.g., Shleifer and Vishny (1992); Pulvino (1998, 1999); Strömberg (2000); Thorburn (2000); Campbell et al. (2011)). However, this literature has typically ignored any spillover effects of bankruptcy on non-bankrupt firms. This paper shows that these externalities are large enough to be a first-order consideration in assessing the costs and benefits of the two bankruptcy regimes.

Two recent studies examine the spillover effects of the closure of large retail chains. Benmelech et al. (2014) document that following a retail chain's shutdown, stores located in the same shopping mall are more likely to close as well. Shoag and Veuger (2014) find that after a big-box store closes, consumers rapidly reduce their visits to nearby stores. While related, our paper differs in several 
regards. Our focus is on the externalities of the two main bankruptcy procedures - reorganization and liquidation. We do so through an identification strategy that exploits the random allocation of bankruptcy judges. This not only allows for a tight identification of the spillovers of liquidation, but these spillovers are estimated relative to the policy-relevant option of reorganization, which may also include establishment shutdowns that are not forced. Moreover, we use establishment-level data from the U.S. Census Bureau, which allows us to study all sectors and hence provide a rich characterization of the spillovers of liquidation and reorganization, and the mechanisms through which these spillovers occur.

Second, this paper contributes to the large literature that studies the benefits of agglomeration. Ellison and Glaeser (1997) show that there is significant geographic clustering of industries, and many theories exist as to why firms co-locate. To date, the empirical literature on agglomeration spillovers has mostly focused on the expansion of agglomeration economies through entry decisions (e.g., Rosenthal and Strange (2003); Greenstone et al. (2010)). ${ }^{6}$ In contrast, our study examines the disruption of agglomeration economies. By focusing on disruptions that break agglomeration linkages through liquidation, and through the reliance on random variation in the assignment of bankruptcy judges, we show how agglomerations can propagate negative shocks that impose negative externalities on other firms within the cluster. ${ }^{7}$ Further, our detailed micro-level data and clean identification scheme allow us to examine more closely the various channels of agglomeration spillovers across a wide range of industries and with more precise geographic locations. This is in contrast to most of the literature on agglomeration that examines the manufacturing industry only, which is typically found disproportionately in small- and medium-size cities, as well as the rural fringes of cities, rather than in dense cities (Kolko (2000)).

Finally, our paper contributes to the growing literature in macroeconomics that studies the propagation of shocks across industries and firms (e.g., Acemoglu et al. (2012); Carvalho (2014); Acemoglu et al. (2016)). In this vein, our paper shows how the (quasi-)random liquidation of an

\footnotetext{
${ }^{6}$ Two exceptions include Jofre-Monseny et al. (2015), who study the closure of large manufacturing plants in Spain, and Gathmann et al. (2016), who examine the spillovers effects of mass layoffs in Germany.

${ }^{7}$ Note that agglomeration spillovers arising from an expansion versus disruption of agglomeration economies need not be symmetric. Indeed, several theories of agglomeration highlight agglomerations' ability to absorb negative shocks (e.g., Krugman (1991)). In fact, as discussed above, liquidation may even benefit the local area if the liquidated establishment's capital and labor are redeployed efficiently within the agglomeration.
} 
establishment propagates through the establishment's agglomeration and ultimately affects local employment.

The remainder of the paper is organized as follows. Section II discusses the institutional background. Section III presents the data. Section IV describes the methodology. Section V provides the results. Section VI concludes.

\section{Institutional Background}

Bankruptcy procedures can be broadly classified into two main categories: liquidation through a cash auction, and reorganization through a structured bargaining process (Hart (2000)). The U.S. Bankruptcy code contains both procedures, with liquidation falling under Chapter 7 and reorganization taking place under Chapter 11 of the code. Bankruptcy formally begins with the filing of a petition for protection under one of the two chapters. In nearly all cases, it is the debtor that files the petition and chooses the chapter of bankruptcy, although under certain circumstances creditors can also file for an involuntary bankruptcy. Firms can file for bankruptcy where they are incorporated, where they are headquartered, or where they do the bulk of their business (see 28 USC $\S 1408)$, thereby giving the largest, nationwide firms some leeway in the choice of bankruptcy venue. However, once a firm files for bankruptcy, it is randomly assigned to one of the bankruptcy judges in the divisional office in which it files. This random assignment is a key part of our identification strategy, which we outline in Section IV.

Firms that file for Chapter 7 bankruptcy expect to liquidate all assets of the firm, and hence face a relatively straightforward process, although it can be lengthy (Bris et al. (2006)). A trustee is put in place to oversee the liquidation of the assets of the firm, and proceeds from the asset sales are used to pay back creditors according to their security and priority. According to U.S. Court filing statistics, liquidations are frequent, as about $65 \%$ of all business bankruptcy filings in the U.S. are Chapter 7 filings.

A significant portion of firms that originally file for Chapter 11 bankruptcy also end up in Chapter 7 through case conversion. Conversion to Chapter 7 occurs when the bankruptcy judge approves a petition to convert the case. Conversion petitions are typically filed either by a creditor 
or the court itself (e.g., by a trustee), accompanied with a brief which outlines why liquidation will provide the highest recovery for the creditors. ${ }^{8}$ Importantly, while there are uniform criteria by which a judge may convert a case from Chapter 11 to Chapter 7, there is significant variation in the interpretation of these criteria across judges. The random allocation of bankruptcy judges thus results in the assignment of similar companies to judges who differ in their propensity to trigger liquidation. As we discuss in Section IV, we exploit this heterogeneity among judges to instrument for the probability that a given company is liquidated.

Firms that remain in Chapter 11 pass through a structured bargaining process in which management and creditors negotiate a plan that outlines any restructuring that will be undertaken, including instituting a new capital structure or selling assets. As shown in Bernstein et al. (2016), a significant number of assets are sold and many firms are completely shut down even if they remain in Chapter 11. The key difference between the two bankruptcy regimes is that in Chapter 7 liquidation is forced, while in Chapter 11 it is only an option. Meanwhile, negotiations in Chapter 11 are subject to a variety of bargaining costs and principal-agent conflicts that may result in inefficient outcomes. This is important to keep in mind, as establishments that remain in Chapter 11 serve as the counterfactual in our analysis. Thus, we compare spillovers of establishments that are forced to be shut down in liquidation to those of establishments that are still bankrupt - and hence may be sold or shut down-but pass through the reorganization process.

\section{Data}

\section{A. Bankruptcy Data}

We gather data on Chapter 11 bankruptcy filings from LexisNexis Law, which obtains filing data from the U.S. Courts system. These data contain legal information about each filing, including the date the case was filed, the court in which it was filed, the judge assigned to the case, an indicator of whether the filing was involuntary or not, and status updates on the case. From the status updates, we are able to identify cases that were converted to Chapter 7. The LexisNexis dataset contains a

\footnotetext{
${ }^{8}$ We examined court documents for a random sample of 200 cases and found that, on average, a motion to convert a case occurs 4 months after the bankruptcy filing. Importantly, in nearly all cases this is the first major motion on which a judge rules.
} 
few bankruptcies beginning as early as 1980, but coverage is not complete in these early years as courts were still transitioning to an electronic records system. We begin our sample in 1992, when LexisNexis' coverage jumped to over 2,000 bankruptcy filings per year (from 450 in 1991) across 70 different bankruptcy districts (out of 91). By 1995, LexisNexis covers essentially $100 \%$ of all court cases across all bankruptcy districts. ${ }^{9}$ We end our sample with cases that were filed in 2005 so as to be able to track economic activity near bankrupt firms for a five-year period after the bankruptcy filing.

\section{B. Establishment-Level Data}

The establishment-level data are obtained from the U.S. Census Bureau's Longitudinal Business Database (LBD). An establishment is a "single physical location where business is conducted" (Jarmin and Miranda (2002)), e.g., a retail store, supermarket, restaurant, warehouse, or manufacturing plant. The LBD covers all business establishments in the U.S. with at least one paid employee. Importantly, the LBD allows us to identify all establishment locations of the bankrupt firms, and also identify geographically proximate establishments that may be affected by the bankruptcy.

We match bankruptcy filings from LexisNexis to the bankrupt firms' establishments in the LBD using the procedure of Bernstein et al. (2016). Specifically, we match the bankruptcy filings from LexisNexis to the U.S. Census Bureau's Business Register - the Standard Statistical Establishment List (SSEL) — using the employer identification number (EIN), which is contained in both datasets. Importantly, each legal entity of a firm can have a separate EIN, and thus there can be multiple EINs (and multiple bankruptcy filings) for each firm. Further, an EIN can have multiple establishments in the LBD. We match bankrupt EINs to all establishments in the SSEL in the year of the bankruptcy filing to form our initial sample of 129,000 bankrupt establishments belonging to 28,000 unique firms. ${ }^{10}$

\footnotetext{
${ }^{9}$ See Iverson (2015) for more information on the LexisNexis data.

${ }^{10}$ Note that the Census Bureau requires us to round observation counts.
} 


\section{Geographical Units}

In our baseline analysis, we define a location at the level of the Census block. Census blocks are the smallest geographic area for which the Census Bureau reports information. In a city, the shape of a Census block follows the geographic pattern of the streets, usually a rectangular grid. Census blocks in suburban and rural areas may be large, irregular, and bounded by a variety of features, such as roads, streams, and transmission lines (U.S. Census Bureau (1994)). There are more than 11 million blocks in the 2010 Decennial Census. ${ }^{11}$

Census blocks serve as a valuable source for small-area geographic studies (e.g., Echenique and Fryer (2007); Bayer et al. (2008)). They are especially appealing in our context since establishments are small economic entities. Arguably, blocks are likely to best approximate the area that is economically relevant to the establishment.

The Census Bureau started collecting block information for business establishments as of the 1992 Census. This coincides with the initial year of our sample. However, block coverage is incomplete in 1992 and becomes increasingly more comprehensive in subsequent Census years. To fill in missing geo codes, we use the most recent block information (e.g., if an establishment has no block information available in 1992, but does in 1997, we fill in the pre-1997 years with the 1997 block code). Out of the initial 129,000 establishments of the bankrupt firms, we obtain a final sample of 91,000 establishments (belonging to 20,000 unique bankrupt firms) with non-missing block information. ${ }^{12}$

We also examine how bankruptcy regimes affect larger areas. Census block groups are the next level above Census blocks in the geographic hierarchy. A Census block group is a set of one or more contiguous Census blocks. There are about 220,000 block groups in the 2010 Decennial Census. Finally, the largest area we consider is the Census tract. A Census tract usually covers a contiguous area and contains up to nine block groups. There are about 74,000 tracts in the 2010 Decennial

\footnotetext{
${ }^{11}$ Note that Census blocks are not delineated based on population. In fact, about $45 \%$ of the Census blocks do not have any population, while a block that includes an apartment complex might have several hundred inhabitants (U.S. Census Bureau (1994)).

${ }^{12} \mathrm{~A}$ related issue is that block boundaries are sometimes redrawn, which could lead to inconsistent block codes over time. To mitigate this issue, we replace inconsistent block codes by the most recent block code (e.g., if an establishment has inconsistent block codes in 1996 and 1997, we use the 1997 block code). This correction is immaterial for our results - we obtain almost identical estimates if we use the opposite approach, that is, rely on the earliest available block code to fix inconsistencies.
} 
Census.

\section{Summary Statistics}

Table I provides summary statistics for the 91,000 establishments belonging to 20,000 firms that

filed for Chapter 11. Out of these establishments, 16,000 pertain to firms that were converted to Chapter 7 liquidation (8,000 firms), while the remaining 75,000 establishments belong to firms that stay in Chapter 11 reorganization (12,000 firms). Note that approximately $40 \%$ of the bankrupt firms filing for Chapter 11 convert to Chapter 7.

As can be seen, Chapter 7 establishments are on average smaller compared to Chapter 11 establishments (28.0 versus 38.8 employees), have lower payroll per employee (\$19,600 versus $\$ 22,700$ ), and belong to smaller companies (2.7 versus 8.1 establishments; 72 versus 309 employees). The latter is in line with prior research documenting that Chapter 7 firms tend to be smaller than Chapter 11 firms (e.g., Bris et al. (2006)).

The table also provides additional statistics at the block, block group, and tract level. As is shown, the average Census block in our sample consists of 55.5 establishments corresponding to 1,105 employees. When we contrast the blocks of Chapter 7 and Chapter 11 establishments, we observe again systematic differences. In particular, Chapter 7 blocks are on average smaller (50.6 versus 56.5 establishments; 926 versus 1,143 employees), and they are populated by smaller establishments (16.1 versus 19.5 employees per establishment).

Overall, the differences in Table I highlight the importance of selection into the bankruptcy regimes, and hence the need for identification in assessing the externalities of liquidation versus reorganization. We discuss our identification strategy in detail in the next section.

\section{Identification Strategy}

\section{A. Empirical Design}

Quantifying the externalities of liquidation (Chapter 7) relative to reorganization (Chapter 11) is challenging due to the inherent selection into bankruptcy regimes. For example, companies 
filing for Chapter 7 directly may operate in declining areas, which could bias our estimate of local externalities. To mitigate this selection issue, we focus only on firms that filed for Chapter 11 reorganization, and exploit the fact that a significant fraction (40\%) of these firms are converted to Chapter 7 liquidation subsequently. We then quantify the local externalities of liquidation by estimating the following specification:

$$
Y_{l, t+m}=\alpha+\beta \cdot \text { Liquidation }_{p i t}+\gamma \cdot X_{l p i t}+\mu_{k}+\epsilon_{l p i}
$$

where $l$ indexes location (e.g., blocks, block groups, and tracts) around bankrupt establishment $p$, that belongs to bankrupt firm $i$. The year of the bankruptcy filing is $t$ and $k$ defines the industry of the bankrupt firm. The main dependent variable $Y_{l, t+m}$ is the annualized percentage change in employment at the location $l$ of the bankrupt establishment (excluding employment of the bankrupt establishment itself) in the $m$ years following the bankruptcy filing year. In most of the analysis we will focus on the 5 years after the bankruptcy filing. ${ }^{13}$ Other dependent variables, such as the change in the number of plants, are similarly defined as percent changes from their level in the year of the bankruptcy filing. ${ }^{14}$ Liquidation $_{\text {pit }}$ is a dummy variable equal to one if establishment $p$ belongs to a company $i$ whose Chapter 11 filing (in year $t$ ) is converted into Chapter 7 liquidation. The decision of whether the case is converted to Chapter 7 liquidation or remains in Chapter 11 reorganization is typically taken in the bankruptcy filing year. ${ }^{15} X_{l p i t}$ is a vector of pre-bankruptcy characteristics at the establishment, firm, and location level. ${ }^{16}$ We further include 2-digit NAICS industry fixed effects to account for unobserved heterogeneity at the industry level. The coefficient of interest is $\beta$ which captures the local externalities of liquidation relative to reorganization.

\footnotetext{
${ }^{13}$ More precisely, $y=\frac{\# e m p_{5}-\# e m p_{0}}{\# e m p_{0}}$, where \#emp is the total number of employees at the location of the bankrupt establishment (net of the employees of the bankrupt establishment). Year 0 is the year of the bankruptcy filing. Year 5 is five years after the bankruptcy filing. For ease of exposition, we annualize this five-year growth rate.

${ }^{14}$ To mitigate the impact of outliers, we trim all dependent variables at the 5 th and 95 th percentiles of their empirical distribution.

${ }^{15}$ To verify this, we examined the court documents of 200 randomly selected cases in our sample, and found that for the median case the time between case filing and a decision on whether the case will remain in Chapter 11 or be converted to Chapter 7 is 4 months.

${ }^{16}$ The firm-level controls include i) $\log$ (employment) of the bankrupt firm, ii) $\log$ (establishments) of the bankrupt firm, and iii) a dummy variable indicating whether other related firms (e.g., subsidiaries of the same firm) also filed for bankruptcy at the same time. The establishment-level control is log(employment) of the bankrupt establishment. Finally, the block-level control is $\log ($ employment) in the block of the bankrupt establishment. All controls are measured in the year of the bankruptcy filing (year 0).
} 
A caveat of specification 1 is that, even among Chapter 11 filers, there might be a substantial amount of selection among firms that convert to Chapter 7. Symptomatic of this issue are the differences in Table 1 - e.g., Chapter 7 firms have fewer establishments, fewer employees, and operate in smaller Census blocks. Naturally, these differences raise concerns that Chapter 7 firms may differ based on unobservables as well. For example, firms that are converted to Chapter 7 may typically reside in less resilient areas. Under this scenario, a negative shock at the local level may trigger both the conversion to Chapter 7 and the decline of the local area.

To mitigate this concern, we use an instrumental variable that exploits the heterogeneity among bankruptcy judges in their propensity to convert Chapter 11 filings into Chapter 7 liquidation. This instrument does not rely on differences in actual bankruptcy laws, as the bankruptcy code is uniform at the federal level. Rather, the instrument makes use of the fact that bankruptcy judges' interpretation of the law varies significantly (e.g., LoPucki and Whitford (1993); Bris et al. (2006); Chang and Schoar (2013)).

Bankruptcy judges work in 276 divisional offices across the U.S., each of which pertains to one of 94 U.S. Bankruptcy Districts. A firm filing for bankruptcy may choose to file either where it is i) headquartered, ii) incorporated, or iii) does most of its business. Once a filing is made in a particular division, judge assignment is random. ${ }^{17}$ We can then rely on this random assignment to generate exogenous variation in the probability that a given case is converted to Chapter 7 , since judges vary in their propensity to convert filings. We implement this instrumental variable approach by estimating the following first-stage regression:

$$
\text { Liquidation }_{\text {pit }}=\rho+\pi \cdot \text { ShareCasesConverted }_{j}+\lambda \cdot X_{l p i t}+\delta_{d t}+\mu_{k}+\eta_{l p i}
$$

where ShareCasesConverted $j$ is the share of Chapter 11 cases that judge $j$ ever converted to

\footnotetext{
${ }^{17}$ As an example, consider the bankruptcy district of New Jersey, which is divided into three divisions: Camden, Newark, and Trenton. The Local Rules of the New Jersey Bankruptcy Court lay out exactly which counties pertain to each division, and firms must file in the division "in which the debtor has its principal place of business." Once a case is filed in a particular division, the Local Rules state that "case assignments shall be made by the random draw method used by the Court" (D.N.J. LBR 1073-1). More broadly, the random assignment of bankruptcy judges within districts is an important feature of the U.S. bankruptcy process. The rationale is to help ensure a fair distribution of cases and prevent "judge shopping," or parties' attempts to have their cases heard by the judge who they believe will act most favorably (see, e.g., Federal Judicial Center (2016)).
} 
Chapter 7, excluding the current case. ${ }^{18}$ Importantly, the inclusion of division by year fixed effects, $\delta_{d t}$, ensures that we exploit the random variation in judge assignment within a division-year cell. The coefficient $\pi$ captures the extent to which a judge $j$ 's propensity to convert a case to Chapter 7 affects the probability that a given case is converted into Chapter 7 liquidation.

We then estimate the following second-stage regression:

$$
y_{l, t+m}=\alpha+\beta \cdot \overline{\text { Liquidation }_{p i t}}+\gamma \cdot X_{l p i t}+\delta_{d t}+\mu_{k}+\epsilon_{l p i}
$$

where $\overline{\text { Liquidation }_{p i}}$ are the predicted values from the first-stage regression. The second-stage regression mirrors the OLS regression in equation (1), except that it relies on the exogenous component of Liquidation - i.e., the component that is induced by the randomization of bankruptcy judges.

In all regressions, we cluster standard errors at the division by year level. Doing so accounts for any arbitrary correlation of the error terms within bankruptcy courts. Lastly, we weight all regressions by the inverse of the number of establishments operated by the bankrupt firm to ensure that each firm receives the same weight and hence avoid overweighting large bankruptcy cases.

If the conditions for a valid instrumental variable are met, $\beta$ captures the causal effect of Chapter 7 liquidation on local employment and other outcomes of interest, relative to reorganization. It is important to note that the estimates in the instrumental variables analysis are coming only from the sensitive firms - i.e., firms that switch bankruptcy regimes because they were randomly assigned to a judge who commonly converts cases to Chapter 7 (Imbens and Angrist (1994)). Clearly, some firms will stay in Chapter 11 no matter the judge, and other firms will convert to Chapter 7 regardless of the judge. Thus, the instrumental variables estimates only capture the local average treatment effect on the sensitive firms, and should be interpreted as such.

\footnotetext{
${ }^{18}$ This standard leave-one-out measure deals with the mechanical relationship that would otherwise exist between the instrument and the conversion decision for a given case. We have experimented with alternative definitions of the instrument as well: i) the share of cases that judge $j$ converted to Chapter 7 in the five years prior to the current case; and ii) judge fixed effects. Both the first and second stage results are unaffected by the choice of the instrument.
} 


\section{B. Validity of the Instrument}

To be valid, our instrument needs to bring about significant changes in the probability of converting a Chapter 11 filing into Chapter 7 liquidation (rank condition). Moreover, the instrument needs to be unrelated to the evolution of the bankrupt establishment's local area (exclusion restriction). In the following, we discuss both conditions.

\section{B.1. First Stage}

Table II presents the results of the first-stage regression, which confirms that the instrument strongly affects the probability of conversion to Chapter 7 liquidation. In column (1), the regression includes division by year fixed effects. In column (2), we also include control variables. In column (3), we further include industry fixed effects. As is shown, the coefficient of share of cases converted is economically large and highly significant in all specifications. The estimates of 0.58-0.59 imply that a one-standard deviation increase in the instrument (0.13) corresponds to an increase in the probability of Chapter 7 liquidation by $7.5-7.6 \%$, a $12.2-12.3 \%$ increase compared to the unconditional probability of $40 \%$. In addition, the instrument is "strong" in a statistical sense. The $F$-statistic ranges between 75.7 and 80.0, which is well above the $F=10$ threshold of Staiger and Stock (1997) and the critical values of Stock and Yogo (2005). This alleviates concerns about weak instruments.

\section{B.2. Exclusion Restriction}

The exclusion restriction requires that our instrument, judge leniency, has no direct effect on postbankruptcy changes in employment at the location of the bankrupt establishment other than through the effect on the probability of conversion to Chapter 7 liquidation. The random allocation of bankruptcy judges, while not sufficient, strongly supports that the exclusion restriction is satisfied-analogous to the ideal setting of randomized experiments. In Table III we conduct randomization tests showing that the instrument is uncorrelated with a large set of covariates and industry fixed effects.

Column (1) shows that the $R^{2}$ from regressing the share of cases converted on division-by-year fixed effects alone is 0.78 , suggesting that there is substantial variation in judge conversion propen- 
sities between divisions and over time. However, the random assignment of judges occurs within court divisions, and therefore, we want to verify that covariates are orthogonal to the instrument conditional on the division-by-year fixed effects. In columns (2)-(5), we include industry fixed effects and controls. Column (2) includes the baseline controls. In columns (3)-(5), we further include pre-trends in employment (that is, the change in employment in the three years preceding the bankruptcy filing in the block, block group, and tract, respectively, of the bankrupt establishment) as well as controls for the block's industry composition, which include the share of employment in the block that is in tradable and non-tradable industries (compared to the omitted category of services). As can be seen, none of the controls is statistically significant and all point estimates are close to zero. Further, the industry fixed effects are jointly insignificant, and the $R^{2}$ remains unchanged in all specifications. Overall, this evidence lends strong support to the randomization assumption.

\section{Results}

\section{A. Main Results}

Table IV presents the main results, in which we focus on how liquidation affects neighboring firms, relative to reorganization. In columns (1)-(2), the dependent variable is the annualized percentage change in employment in the block of the bankrupt establishment within the five-year period following the bankruptcy filing (excluding employment of the bankrupt establishment itself). All regressions include the baseline controls, industry fixed effects, and division by year fixed effects. The OLS estimate reported in column (1), which does not account for selection, shows that liquidation is associated with an annual employment growth rate that is 2.5 percentage points lower relative to reorganization. The IV-2SLS estimate in column (2), which relies on the random assignment of bankruptcy judges, is somewhat larger in magnitude. It implies that liquidation leads to an annual employment growth rate that is 4.0 percentage points lower relative to reorganization.

To better understand how to interpret the magnitudes of the effect, it is important to note that the liquidation effect captured here is at the block level (we will consider larger geographical 
units in Section III.C below). Since the average number of employees in the blocks of Chapter 7 establishments is 926 (Table I), this coefficient implies that liquidation leads to a decrease in block-level employment by 37 employees per year, relative to reorganization. A simple back-ofthe-envelope calculation indicates that this estimate corresponds to a multipler of approximately 1.3, that is, for every job that is lost at the liquidated establishment, another 1.3 jobs are lost due to spillovers. ${ }^{19}$ Interestingly, this estimate is in the ballpark of other multipliers that have been estimated in the agglomeration literature. In particular, following the opening of a manufacturing plant, Moretti (2010) estimates a multiplier in the range of 1.0-2.5.

In columns (3)-(4), the dependent variable is the annualized percentage change in the number of establishments in the block of the bankrupt establishment within the five-year period following the bankruptcy filing (again excluding the bankrupt establishment). The results mirror those in columns (1)-(2). Specifically, the estimates imply that the number of establishments drops by $3.7 \%$ to $4.7 \%$ per year. Overall, the results in Table IV indicate that liquidation imposes large negative externalities on the immediate surroundings of the liquidated establishment.

In Figures 1 and 2, we examine the dynamics of the local externalities at the block level. Specifically, we estimate variants of the regressions in columns (2) and (4) of Table 4, but instead of using as the dependent variable the annual change in employment (and number of establishments, respectively) over a five-year period, we now consider horizons of 1 to 5 years following the filing date and report the cumulative change in employment.

Figure 1 plots the coefficients (along with the 95\% confidence bounds) pertaining to the employment regressions. As can be seen, the local externalities take time to materialize. After one year, the decrease in employment is relatively modest. It is only after two years that it becomes

\footnotetext{
${ }^{19}$ The calculation is as follows. Our IV-2SLS estimate implies that block-level employment (net of the liquidated establishment's employment) decreases by $4 \%$ annually, corresponding to 37 employees annually, within the five-year period following the bankruptcy filing. One complication, however, is that some of these employees may find jobs within the broader labor market. To obtain a rough estimate of the reallocation, we rely on the estimates from Section V.C, in which we study broader geographies. In particular, we document that tract-level employment (net of the affected block) increases by $0.5 \%$, which suggests that some of the employment losses in the block of the liquidated establishment are offset by reallocation within the tract. The number of employees in the block and tract of the liquidated establishments is 926 and 6,862, respectively (see Table I). Accordingly, the reallocation within the tract amounts to $0.5 \% \times(6,862-926)=29.7$ employees, and hence the net employment losses at the block level are about $37-29.7=7.3$ employees. Since these are annual figures, and since the effect takes five years to unfold, the five-year employment losses are $5 \times 7.3=36.5$ employees. Finally, since the average liquidated establishment has 28 employees (Table I), the corresponding muliplier is 1.3. Naturally, we caveat that this calculation is based on simplifying assumptions, and is only meant to provide a rough ballpark.
} 
sizable and statistically significant. Finally, the effect stabilizes somewhat after four to five years. Similarly, in Figure 2, we repeat this analysis for the number of establishments. The results mirror those for employment. We find that the number of establishments declines monotonically and becomes statistically significant in year 3 and stabilizes in years 4 and 5 .

These results are robust to a variety of alternative specifications. First, we find similar results if we weight the regressions by block-level employment, showing that our results are not driven by small blocks with few employees. Similarly, our results are robust if we split the sample into blocks with above- and below-median total employment in the year of the bankruptcy filing, illustrating again that the results are not driven by the smallest blocks. Second, we verify that outliers are not affecting our estimates by i) trimming the employment change distribution at the 10th and 90th percentiles, and ii) removing blocks whose employment drops to zero within five years of the bankruptcy filing. Both tests yield robust results. Third, we obtain similar results if we drop all cases in which the bankrupt firm had multiple establishments in the same block. Finally, and related, we also obtain similar results if we drop all cases in which multiple establishments (belonging to any firm) entered bankruptcy in the same year in the same block.

\section{B. Decomposing the Effect to Entrants and Existing Establishments}

The previous section explored the spillover effects of liquidation on aggregate employment and the number of establishments, relative to reorganization. In this section we decompose these aggregate effects to examine separately how liquidation spillovers affect existing establishments and how it affects the entry of new establishments to the area. In particular, we are interested in understanding the extent to which the aggregate negative spillovers of liquidation are driven by the disruption of agglomeration linkages among existing firms, and whether liquidation leads to a "creative destruction" process by increasing entry to the area. This creative destruction may occur if liquidation frees up resources such as employees, machinery, and real estate, that were previously unavailable. To do so, we decompose the overall changes in employment into changes in: i) employment of existing establishments ("existing"), and ii) employment of new establishments ("new"): 


$$
\Delta e m p_{p i 5}=\frac{\# e m p_{5}-\# e m p_{0}}{\# e m p_{0}}=\frac{\left(\# e m p_{5}^{\text {new }}-0\right)+\left(\# e m p_{5}^{\text {existing }}-\# e m p_{0}^{\text {existing }}\right)}{\# e m p_{0}}
$$

where \#emp $m$ is the number of employees in a given Census block in year $m$ after the bankruptcy filing (excluding the bankrupt establishment). Similarly, \#empexisting is the number of employees working at establishments that existed in the year of the bankruptcy filing, and \#emp new is the number of employees that are working at establishments that did not exist in the year of the bankruptcy filing and thus entered later into the area. Therefore, this decomposition separately explores the effect of liquidation on the share of employment growth due to existing establishments, and the portion of employment growth due to the entry of new establishments.

We decompose the change in the number of establishments analogoulsy. Specifically, we distinguish between changes in the number of existing establishments due to establishment closures, and changes in entry due to establishment openings:

$$
\Delta \text { plants }_{\text {pi5 }}=\frac{\# \text { plants }_{5}-\# \text { plant }_{0}}{\# \text { plant }_{0}}=\frac{\left(\# \text { plants }_{5}^{\text {birth }}-0\right)+\left(0-\# \text { plant }_{0}^{\text {death }}\right)}{\# \text { plant }_{0}} .
$$

The results are presented in panels (a) and (b) of Table V. ${ }^{20}$ In columns (2)-(3) of panel (a), we estimate variants of the baseline specification (reproduced in column (1)), decomposing the change in employment into its two components. As can be seen, the decline in employment operates mostly through a decrease in employment within existing establishments of 3 percentage points per year, which captures $75 \%$ of the overall effect. To a lesser extent, the effect is also driven by a decline in employment due to less entry into the region of 1 percentage point per year (which captures $25 \%$ of the overall effect). We obtain a similar pattern in panel (b) where we decompose the number of establishments into closures and openings. As is shown, most of the effect comes from the closure of existing establishments.

These results are inconsistent with the creative destruction argument, according to which liquidation could help revitalize the local area by freeing up resources of distressed establishments to

\footnotetext{
${ }^{20}$ As in the main analysis, we annualize the changes in employment (and number of establishments, respectively).
} 
induce entry. Instead, our estimates indicate that, if anything, liquidation slightly deters entry into the area, while simultaneously reducing employment at existing establishments.

\section{Different Geographical Areas}

In the analysis so far, we examined the spillovers of liquidation at the Census block level-the smallest geographic unit used by the Census Bureau. This choice is intuitive given the small size of the average bankrupt establishment. Nevertheless, it is instructive to study larger geographies as well to explore how far reaching the relative effect of liquidation is. To do so, we explore spillover effects of bankruptcy in Census block groups and Census tracts. Following the terminology of Section V.B, we separately explore the effect of liquidation on aggregate employment in panel (a) of Table VI, employment in existing establishments in panel (b), and employment associated with entry in panel (c).

In column (2) of panel (a), we examine how liquidation affects aggregate employment at the block group level. Census block groups are the next level above Census blocks in the geographic hierarchy, and consist of a set of contiguous blocks. As is shown, the drop in employment is smaller $(-1.7 \%)$ and marginally insignificant $(t=1.60)$. This suggests that the externalities of liquidation are localized - they are substantial in the immediate neighborhood of the liquidated establishment and decay with distance. In column (3), we further examine the impact of liquidation on employment at the tract level. Not surprisingly, no effect is found within such large areas - the coefficient is virtually zero and highly insignificant. ${ }^{21}$ The results are consistent with prior literature that illustrate that spillover effects decay quickly with geographic distance (Rosenthal and Strange (2003); Arzaghi and Henderson (2008); Ahlfeldt et al. (2015)).

In columns (4)-(5) of panel (a), we examine the potential reallocation of employees within broader geographies. To do so, we consider the change in employment in the block group (and tract, respectively), net of the block of the bankrupt establishment. As is shown, we find some evidence of reallocation within the tract. Specifically, the coefficient in column (5) is positive (0.005), although not statistically significant. This might suggest that some of the employment losses in the block of

\footnotetext{
${ }^{21}$ Note that the latter can be interpreted as a placebo test. Indeed, within a tract, the economic relevance of a liquidated establishment is trivial. Hence, finding any effect at the tract level would be symptomatic of omitted variables or other form of non-randomness in the allocation of bankruptcy judges.
} 
the liquidated establishment are offset by reallocation within the tract. Indeed, given that tracts are more than seven times larger than blocks, taking this point estimate at face value would suggest that roughly $80 \%$ of the effect at the block-level is offset by increases in employment elsewhere in the tract. ${ }^{22}$

We repeat the analysis separately for existing establishments in panel (b) and for new establishments in panel (c). As expected, we find that the results in panel (b) mirror the results in panel (a), and the spillover effects on existing establishments decay for larger geographical units. In panel (c) we can further explore the "creative destruction" hypothesis that liquidation triggers entry, but this time, using larger geographical units such as Census block groups and Census tracts. Similar to the evidence in Section V.B, we find no evidence for increased entry following liquidation events. In fact, in all geographical units we find that the coefficient of liquidation is negative, as shown in columns (1) through (3). In columns (4) and (5) we focus on Census block groups and Census tracts, respectively, net of the block itself. In both instances the coefficient of liquidation remains negative. In sum, even when exploring larger geographical units, we find no evidence for increased entry following the liquidation of the bankrupt firms, when compared to reorganization.

\section{Industry Sectors and Underlying Mechanisms}

In this section we attempt to shed light on the underlying mechanisms through which bankruptcy generates spillovers on neighboring firms. We focus on three potential mechanisms. Specifically, liquidation may affect (1) customer traffic, (2) synergies between businesses, and (3) local demand for goods and services.

To examine these mechanisms, we decompose employment in each block into three broad industry sectors: (1) the non-tradable sector (e.g., restaurants and retail) that relies on local demand and customer flow to the area, (2) the tradable sector (e.g., manufacturing) that is likely to rely on nonlocal demand, and (3) services (e.g., publishers, lawyers, accountants, and advertisement agencies, among others). ${ }^{23}$ This decomposition is provided in panels (a), (b), and (c), respectively, of Table

\footnotetext{
${ }^{22}$ The average block has 926 total employees and the average tract has 6,862 total employees. Accordingly, employment losses in the block of the liquidated establishment amount to $4 \% \times 926=37$ employees, while the reallocation within the tract amounts to $0.5 \% \times(6,862-926)=29.7$ employees. However, this is a rough figure, as the point estimates are not tightly estimated.

${ }^{23}$ We identify service industries using the classification of the Census (www.census.gov/econ/services.html). In
} 
VII. In each panel, column (1) considers all bankruptcies, whereas columns (2)-(4) only consider bankruptcies in the non-tradable, services, and tradable sectors, respectively. In other words, the first column of each panel shows how the overall effect of -0.040 from column (2) of Table IV is decomposed across these three broad industry sectors: -0.014 comes from a decline in non-tradable employment, -0.029 from services, and 0.003 from the tradable sector. Thus, the overall decline in employment is driven by the non-tradable and services sectors. The results in columns (2)-(4) of Table VII then provide all $3 \times 3=9$ combinations of sector-specific block-level employment and sector-specific bankruptcies. We can shed light on which mechanism is driving the overall effects by examining how bankruptcies affect employment within and across these industry sectors.

We begin with the first channel, that is, the possibility that liquidation reduces customer traffic to a specific area. In panel (a), the dependent variable is employment growth at the block level in the non-tradable sector. The non-tradable sector, which includes establishments such as restaurants and retail stores, depends on local demand, and therefore may be affected by a decline in customer traffic to the area triggered by liquidation. In column (1) we find that, on average, liquidation leads to a decline in employment growth in the non-tradable sector. In column (2), we focus only on bankruptcies in the non-tradable sector and find that the liquidation of non-tradable establishments (which likely attract customers) strongly affects other non-tradable establishments in the area. In contrast, liquidation of establishments in the services or tradable sectors has no spillover effect on non-tradable employment.

The finding in panel (a) that non-tradable liquidations affect non-tradable employment-but not liquidation in other sectors - is consistent with the customer traffic channel. Indeed, the effect is found in cases where customer traffic is likely to be reduced but only among firms that rely on customer traffic for demand (i.e., restaurants and retail). Intuitively, the liquidation of, say, a retail store may deter customers from driving to the area, which in turn may hurt nearby restaurants. In addition, two other findings are supportive of this channel. First, the fact that the effect dissipates quickly at larger geographies is consistent with the customer traffic argument, as customers who

keeping with Mian and Sufi (2014), we define the non-tradable sector as retail trade (NAICS 44-45) and accommodation and food services (NAICS 72). The tradable sector consists of all remaining industries, which are essentially manufacturing (NAICS 31-33). Our results are virtually identical if we strictly restrict the tradable sector to manufacturing. 
are looking to consolidate shopping trips typically do so by concentrating shopping within a single shopping center, which would be within a single Census block. ${ }^{24}$ Second, in Section V.E we show that the employment losses are stronger when the bankrupt establishment remains vacant. As shown in Bernstein et al. (2016), liquidation increases the likelihood of vacancy at a location. While a vacancy will certainly not attract customers, it is possible that it actually deters customers due to low maintenance, neglect, and even crime. Evidence from residential real estate shows that vacant homes and apartments have poor maintenance (Campbell et al. (2011)) and cause higher crime in the immediate area (Spelman (1993); Ellen et al. (2013); Cui and Walsh (2015)). Arguably, the same may apply to commercial real estate, which could further deter customers.

The second potential mechanism is synergies between businesses. Does liquidation reduce business synergies among neighboring firms? Beginning with Marshall (1890), prior literature has posited that industry agglomeration can benefit other firms by: i) increasing the transfer of knowledge and skills, ii) reducing transportation costs of goods, and iii) creating larger labor market pools. More specifically, if ideas and knowledge are more easily transmitted face-to-face, or if informal interaction creates more sharing of knowledge and skills, then geographic proximity can increase the productivity of similar firms. Empirical evidence for this channel includes the spread of knowledge in agriculture (Griliches (1958)), patents (Jaffe et al. (1993)), and high-tech firms (Saxenian (1994)). Similarly, geographic proximity reduces transportation costs for goods when customers and suppliers co-locate (Krugman (1991), Glaeser and Kohlhase (2004)). Finally, agglomeration can create positive spillovers by reducing search frictions in the labor market, thereby providing a better worker-firm match. In addition, large labor markets can provide implicit insurance against idiosyncratic shocks on both the firm and worker side, as workers who are laid off can more easily find a new job, while firms that lose employees face lower costs in hiring replacements (Krugman $(1991))$.

To explore these potential explanations we turn to panels (b) and (c) that explore the services and tradable sectors. In panel (b) the dependent variable is the employment growth at the block level in the services sector. In column (1) we find that liquidation leads to a significant decline

\footnotetext{
${ }^{24}$ Note that nearly all of the bankruptcies in our sample are not those of name-brand "anchor" stores that have been examined in previous studies (Pashigian and Gould (1998); Gould et al. (2005); Benmelech et al. (2014); Shoag and Veuger (2014)). This suggests that even small stores play a significant role in attracting customers.
} 
in employment growth in the services sector. More specifically, as illustrated in columns (2) and (3), the decline in employment in the services sector is triggered by the liquidation of non-tradable establishments and, especially, the liquidation of establishments in the services sector. In contrast, column (4) shows that the liquidation of establishments in the tradable sector does not affect employment growth in the services sector. Meanwhile, in panel (c) we find that the tradable sector is not affected by liquidation in any sector.

These results suggest that the liquidation spillovers we identify are unlikely to arise due to changes in the labor market or transportation costs. First, the benefits of labor market pooling should arguably apply to all sectors, yet we find no effect among tradable firms. Similarly, transportation costs likely matter especially for producers of tradable goods, while they play a small role in production costs for services firms. Our findings are in the opposite direction of this prediction. Second, our effect decays quickly at larger geographies, and is essentially zero at the tract level. Labor markets are much larger than even a Census tract, and similarly agglomeration due to transportation costs likely occurs at a geographic level much larger than a Census block. Hence, it seems unlikely that a decline in labor market pooling or increase in transportation costs may explain our results.

Instead, knowledge spillovers may occur on a very local level. For example, Arzaghi and Henderson (2008) use data on the location of advertising agencies to show that the information benefits of agglomeration begin to decay at a distance as small as 500 meters. This is especially sensible if information transfers rely on informal meetings and face-to-face communication. Thus, if the negative spillovers from liquidation are driven by a loss of business synergies, it is likely due to the loss of knowledge transfers rather than a disruption of the supply chain or labor market of a firm. To the extent that knowledge spillovers are especially important in services, our finding in panel (b) that services bankruptcies affect local services employment is potentially consistent with this mechanism. $^{25}$

The third potential mechanism is the direct local demand channel triggered by the bankrupt firm's employees (Moretti (2010)), which predicts that the liquidation of a bankrupt firm will reduce

\footnotetext{
${ }^{25}$ Given the broad range of services, it is also possible that the customer traffic channel matters for some of these firms. This could explain why the liquidation of non-tradable establishments has a marginally significant effect on services firms.
} 
local demand for goods and services and hence hurt non-tradable establishments. For example, if a manufacturing plant is liquidated, employees losing their jobs at the plant may cut back on their local grocery shopping and restaurant visits. We find no statistically significant evidence of this mechanism. As can be seen in column (4) of panels (a) and (b), the liquidation of tradable establishments does not significantly reduce either non-tradable or services employment. Hence, the evidence is inconsistent with the direct local demand channel.

In sum, while it is difficult to precisely distinguish between these different potential mechanisms, our results appear to be most consistent with liquidation harming knowledge transfers and reducing customer traffic to the area.

\section{E. Fate of the Bankrupt Establishments}

Finally, in Table VIII we examine how the local spillovers of liquidation vary depending on the "fate" of the bankrupt establishment. Broadly speaking, we distinguish between four potential outcomes for the bankrupt establishment: (i) continuer - an establishment that remains operated by the bankrupt firm and maintains the same operations (either in reorganization, or in the years until it winds down in liquidation); (ii) reallocated to the same industry - an establishment that is acquired by another company in the same 2-digit (or 3-digit) NAICS industry as the original bankrupt firm; (iii) reallocated to a different industry - an establishment that is acquired by another company in a different industry as the original bankrupt firm; and (iv) vacant - we observe no economic activity at the location of the establishment. ${ }^{26}$ Intuitively, we would expect the negative externalities to be lowest for continuers, since this outcome does not disrupt the local agglomeration network. However, if reallocated plants are able to employ more workers, or more easily form connections to local firms, they may be less prone to negative externalities.

We examine this heterogeneity by regressing the change in block-level employment on a set of indicator variables that capture the post-bankruptcy status of the bankrupt establishment. We caution that this analysis does not necessarily warrant a causal interpretation. Indeed, while the random assignment of bankruptcy judges provides exogenous variation in the probability of Chapter 7 liquidation or Chapter 11 reorganization, we do not have an instrument for the post-bankruptcy

\footnotetext{
${ }^{26}$ We track establishments' post-bankruptcy status using the methodology of Bernstein et al. (2016).
} 
status (e.g., reallocation versus vacancy). Because of this, these specifications are estimated with regular OLS.

The results are provided in Table VIII. In columns (1)-(6), we include each indicator separately. As shown, the decrease in block-level employment is smallest for continuers, while it is largest for vacant establishments and establishments that are reallocated to a different industry. This pattern also emerges from columns (7)-(8), where we include all indicators jointly, using vacancy as base group. While this evidence should be interpreted cautiously, the findings indicate that the disruption of existing operations, either by switching into another industry or full vacancy, is associated with negative externalities. Such disruptions are more common in liquidation, rather than reorganization, as documented in Bernstein et al. (2016).

\section{Conclusion}

The results presented in this paper show that the liquidation of bankrupt firms imposes large negative externalities on the local economy, when compared to reorganization, an alternative approach to resolve distress in courts. Using the random assignment of bankruptcy judges as a source of exogenous variation in the probability of Chapter 7 liquidation (versus Chapter 11 reorganization), we find that, within a five-year period, employment decreases substantially in the Census block of the liquidated establishment. Most of the decline is due to lower growth of existing establishments and, to a lesser extent, reduced entry into the area. This evidence is inconsistent with a "creative destruction" argument, according to which liquidation would contribute to the revitalization of the area and induce entry.

We further document that the spillover effects are highly localized and concentrate in the nontradable and service sectors, particularly when the bankrupt firm operates in the same sector. These results are consistent with liquidation leading to a reduction in consumer traffic to the local area and reducing knowledge spillovers between firms.

These findings leave a number of important areas open for future research, of which we highlight two here. First, our study examines local spillovers from liquidation. Spillovers can be non-local as well (e.g., the liquidation of an important customer could hurt non-local suppliers). A challenge 
for future research is to establish the relevance and magnitude of such non-local spillovers. Second, we caution that, while our estimates are an important step towards understanding the welfare implications of liquidation and reorganization, there are still many aspects of the welfare question that are not included in our analysis. For example, liquidation could have ex ante benefits by disciplining managers, and it clearly has effects on the firm's creditors that are not considered here. Therefore, our estimates should not be interpreted as showing that liquidation should never be implemented. Extending our analysis to consider these aspects is a difficult, yet exciting, avenue for future research. 


\section{References}

Acemoglu, D., U. Akcigit, and W. R. Kerr (2016). Networks and the macroeconomy: An empirical exploration. NBER Macroeconomics Annual 30(1), 273-335.

Acemoglu, D., V. M. Carvalho, A. Ozdaglar, and A. Tahbaz-Salehi (2012). The network origins of aggregate fluctuations. Econometrica 80(5), 1977-2016.

Aghion, P., O. Hart, and J. Moore (1992). The economics of bankruptcy reform. Journal of Law, Economics and Organization 8(3), 523-546.

Ahlfeldt, G., S. J. Redding, D. M. Sturm, and N. Wolf (2015). The economics of density: Evidence from the Berlin Wall. Econometrica 83(6), 2127-2189.

Arzaghi, M. and J. V. Henderson (2008). Networking off Madison avenue. The Review of Economic Studies 75 (4), 1011-1038.

Baird, D. G. (1986). The uneasy case for corporate reorganizations. Journal of Legal Studies 15(1), $127-147$.

Baird, D. G. (1993). Revisiting auctions in Chapter 11. The Journal of Law ES Economics 36(1), 633-653.

Bayer, P., S. L. Ross, and G. Topa (2008). Place of work and place of residence: Informal hiring networks and labor market outcomes. Journal of Political Economy 116(6), 1150-1196.

Bebchuk, L. A. (1988). A new approach to corporate reorganizations. Harvard Law Review 101, 775-804.

Benmelech, E., N. Bergman, A. Milanez, and V. Mukharlyamov (2014). The agglomeration of bankruptcy. National Bureau of Economic Research Working Paper 20254.

Bernstein, S., E. Colonnelli, and B. C. Iverson (2016). Asset allocation in bankruptcy. U.S. Census Bureau Center for Economic Studies Working Paper CES-WP-16-13.

Black, D., T. McKinnish, and S. Sanders (2005). The economic impact of the coal boom and bust. Economic Journal 115(503), 449-476.

Bradley, M. and M. Rosenzweig (1992). The untenable case for Chapter 11. Yale Law Journal $101(5), 1043-1095$.

Bris, A., I. Welch, and N. Zhu (2006). The costs of bankruptcy: Chapter 7 liquidation versus Chapter 11 reorganization. Journal of Finance 61(3), 1253-1303.

Caballero, R. and M. Hammour (1994). The cleansing effect of recessions. American Economic Review 84, 1350-1368.

Caballero, R. and M. Hammour (1996). On the timing and efficiency of creative destruction. Quarterly Journal of Economics 111, 805-852.

Campbell, J. Y., S. Giglio, and P. Pathak (2011). Forced sales and house prices. American Economic Review 101 (5), 2108-2131. 
Carrington, W. J. (1996). The Alaskan labor market during the pipeline era. Journal of Political Economy 104(1), 186-218.

Carvalho, V. M. (2014). From micro to macro via production networks. Journal of Economic Perspectives 28(4), 23-47.

Chang, T. and A. Schoar (2013). Judge specific differences in Chapter 11 and firm outcomes. Working Paper, University of Southern California.

Cui, L. and R. Walsh (2015). Foreclosure, vacancy and crime. Journal of Urban Economics 87, $72-84$.

Dobbie, W. and J. Song (2015). Debt relief and debtor outcomes: Measuring the effects of consumer bankruptcy protection. American Economic Review 105(3), 1272-1311.

Doyle, J. J. (2008). Child protection and adult crime: Using investigator assignment to estimate causal effects of foster care. Journal of Political Economy 116(4), 746-770.

Duranton, G. and D. Puga (2004). Micro-foundations of urban agglomeration economies. In V. J. Henderson and J.-F. Thisse (Eds.), Handbook of Regional and Urban Economics, Volume 4, pp. 2063-2117. Elsevier/North Holland, Amsterdam.

Echenique, F. and R. G. Fryer (2007). A measure of segregation based on social interactions. Quarterly Journal of Economics 122(2), 441-485.

Ellen, I. G., J. Lacoe, and C. A. Sharygin (2013). Do foreclosures cause crime? Journal of Urban Economics 74, 59-70.

Ellison, G. and E. L. Glaeser (1997). Geographic concentration in U.S. manufacturing industries: A dartboard approach. Journal of Political Economy 105(5), 889-927.

Federal Judicial Center (2016). How the federal courts are organized. Federal Judicial Center, Washington, DC.

Galasso, A. and M. Schankerman (2015). Patents and cumulative innovation: Causal evidence from the courts. The Quarterly Journal of Economics 130(1), 317-369.

Gathmann, C., I. Helm, and U. Schönberg (2016). Spillover effects of mass layoffs. Working Paper, University College London.

Gertner, R. and D. Scharfstein (1991). A theory of workouts and the effects of reorganization law. The Journal of Finance 46(4), 1189-1222.

Gilson, S. C. (1997). Transactions costs and capital structure choice: Evidence from financially distressed firms. Journal of Finance 52(1), 161-196.

Glaeser, E. L. and J. D. Gottlieb (2009). The wealth of cities: Agglomeration economies and spatial equilibrium in the united states. Journal of Economic Literature 47(4), 983-1028.

Glaeser, E. L. and J. E. Kohlhase (2004). Cities, regions and the decline of transport costs. Papers in Regional Science 83(1), 197-228. 
Gould, E. D., B. P. Pashigian, and C. J. Prendergast (2005). Contracts, externalities, and incentives in shopping malls. Review of Economics and Statistics 87(3), 411-422.

Greenstone, M., R. Hornbeck, and E. Moretti (2010). Identifying agglomeration spillovers: Evidence from winners and losers of large plant openings. Journal of Political Economy 118(3), 536-598.

Griliches, Z. (1958). Research costs and social returns: Hybrid corn and related innovations. Journal of Political Economy 66, 419-431.

Hart, O. (2000). Different approaches to bankruptcy. National Bureau of Economic Research Working Paper 7921.

Hotchkiss, E. S. (1995). Postbankruptcy performance and management turnover. Journal of Finance 50(1), 3-21.

Imbens, G. W. and J. D. Angrist (1994). Identification and estimation of local average treatment effects. Econometrica 62(2), 467-476.

Iverson, B. C. (2015). Get in line: Chapter 11 restructuring in crowded bankruptcy courts. Working Paper, Northwestern University.

Jaffe, A. B., M. Trajtenberg, and R. Henderson (1993). Geographic localization of knowledge spillovers as evidenced by patent citations. Quarterly Journal of Economics 108, 577-598.

Jarmin, R. S. and J. Miranda (2002). The longitudinal business database. U.S. Census Bureau Center for Economic Studies Working Paper CES-WP-02-17.

Jofre-Monseny, J., M. Sánchez-Vidal, and E. Viladecans-Marsal (2015). Big plant closures and agglomeration economies. SERC Discussion Paper 179.

Kling, J. R. (2006). Incarceration length, employment, and earnings. American Economic Review $96(3), 863-876$.

Kolko, J. (2000). The death of cities? The death of distance? Evidence from the geography of commercial internet usage. In I. Vogelsang and M. Compaine (Eds.), The Internet Upheaval: Raising Questions, Seeking Answers in Communications Policy, pp. 73-98. Cambridge, MA: MIT Press.

Krugman, P. R. (1991). Geography and Trade. Cambridge, MA: MIT press.

LoPucki, L. M. and W. C. Whitford (1993). Patterns in the bankruptcy reorganization of large publicly held companies. Cornell Law Review 78(4), 597-618.

Marshall, A. (1890). Principles of Economics. New York, NY: MacMillan.

Mian, A. and A. Sufi (2014). What explains the 2007-2009 drop in employment? Econometrica 82(6), 2197-2223.

Moretti, E. (2010). Local multipliers. American Economic Review: Papers and Proceedings 100(2), $1-7$. 
Moretti, E. (2011). Local labor markets. In O. Ashenfelter and D. Card (Eds.), Handbook of Labor Economics, Volume 4, pp. 1237-1313. Elsevier/North Holland, Amsterdam.

Pashigian, B. P. and E. D. Gould (1998). Internalizing externalities: The pricing of space in shopping malls. The Journal of Law and Economics 41(1), 115-142.

Pulvino, T. C. (1998). Do asset fire sales exist? An empirical investigation of commercial aircraft transactions. Journal of Finance 53(3), 939-978.

Pulvino, T. C. (1999). Effects of bankruptcy court protection on asset sales. Journal of Financial Economics 52(2), 151-186.

Rosenthal, S. S. and W. C. Strange (2003). Geography, industrial organization, and agglomeration. Review of Economics and Statistics 85(2), 377-393.

Saxenian, A. (1994). Regional networks: Industrial adaptation in Silicon Valley and route 128. Working Paper, UC Berkeley.

Schumpeter, J. (1934). Depressions: Can we learn from past experiences? In D. Brown, E. Chamberlin, and S. Harris (Eds.), The Economics of the Recovery Program, Volume 4. New York, NY: McGraw-Hill.

Shleifer, A. and R. W. Vishny (1992). Liquidation values and debt capacity: A market equilibrium approach. Journal of Finance 47(4), 1343-1366.

Shoag, D. and S. Veuger (2014). Shops and the city: Evidence on local externalities and local government policy from big box bankruptcies. Working Paper, Harvard University.

Spelman, W. (1993). Abandoned buildings: Magnets for crime? Journal of Criminal Justice 21 (5), 481-495.

Staiger, D. and J. H. Stock (1997). Instrumental variables regression with weak instruments. Econometrica 65(3), 557-586.

Stock, J. H. and M. Yogo (2005). Testing for weak instruments in linear IV regression. In D. W. K. Andrews and J. H. Stock (Eds.), Identification and Inference for Econometric Models: Essays in Honor of Thomas Rothenberg, pp. 80-108. Cambridge, UK: Cambridge University Press.

Strömberg, P. (2000). Conflicts of interest and market illiquidity in bankruptcy auctions: Theory and tests. Journal of Finance 55(6), 2641-2692.

Thorburn, K. S. (2000). Bankruptcy auctions: Costs, debt recovery, and firm survival. Journal of Financial Economics 58(3), 337-368.

U.S. Census Bureau (1994). Geographic areas reference manual. U.S. Department of Commerce, Economics and Statistics Administration. 
Figure 1

Evolution of Employment in the Liquidated Establishments' Blocks

This figure plots the evolution of employment in the Census blocks of Chapter 7 establishments (i.e., establishments belonging to companies that are liquidated) compared to the Census blocks of Chapter 11 establishments (i.e., establishments belonging to companies that are reorganized). The y-axis indicates the (cumulative) percentage change in employment compared to the year of the bankruptcy filing (year 0). The $\mathrm{x}$-axis indicates the year relative to the bankruptcy filing. The dashed lines plot the $95 \%$ confidence bounds.

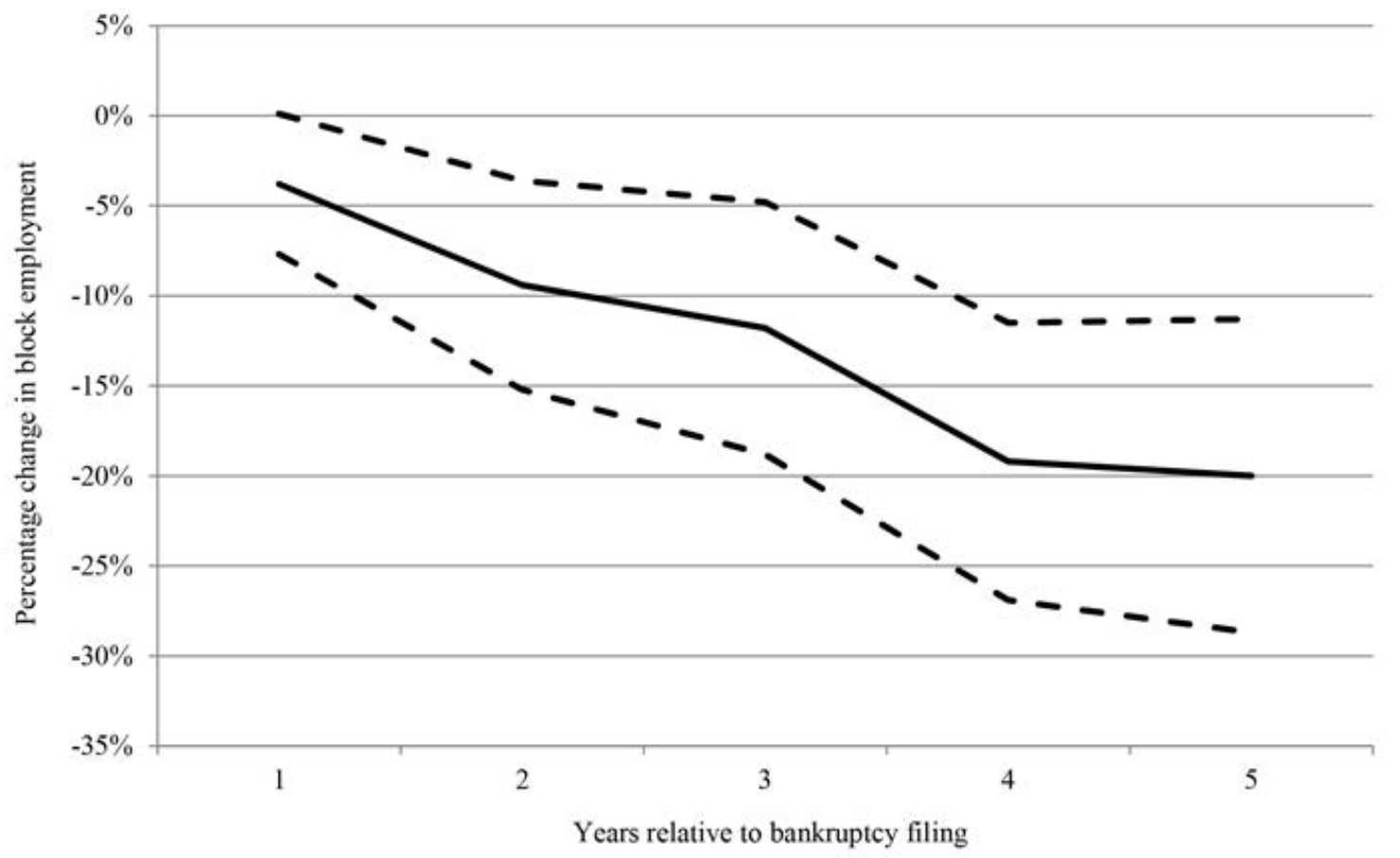


Figure 2

Evolution of the Number of Establishments in the Liquidated Establishments' Blocks This figure plots the evolution of the number of establishments in the Census blocks of Chapter 7 establishments (i.e., establishments belonging to companies that are liquidated) compared to the Census blocks of Chapter 11 establishments (i.e., establishments belonging to companies that are reorganized). The y-axis indicates the (cumulative) percentage change in the number of establishments compared to the year of the bankruptcy filing (year 0). The x-axis indicates the year relative to the bankruptcy filing. The dashed lines plot the $95 \%$ confidence bounds.

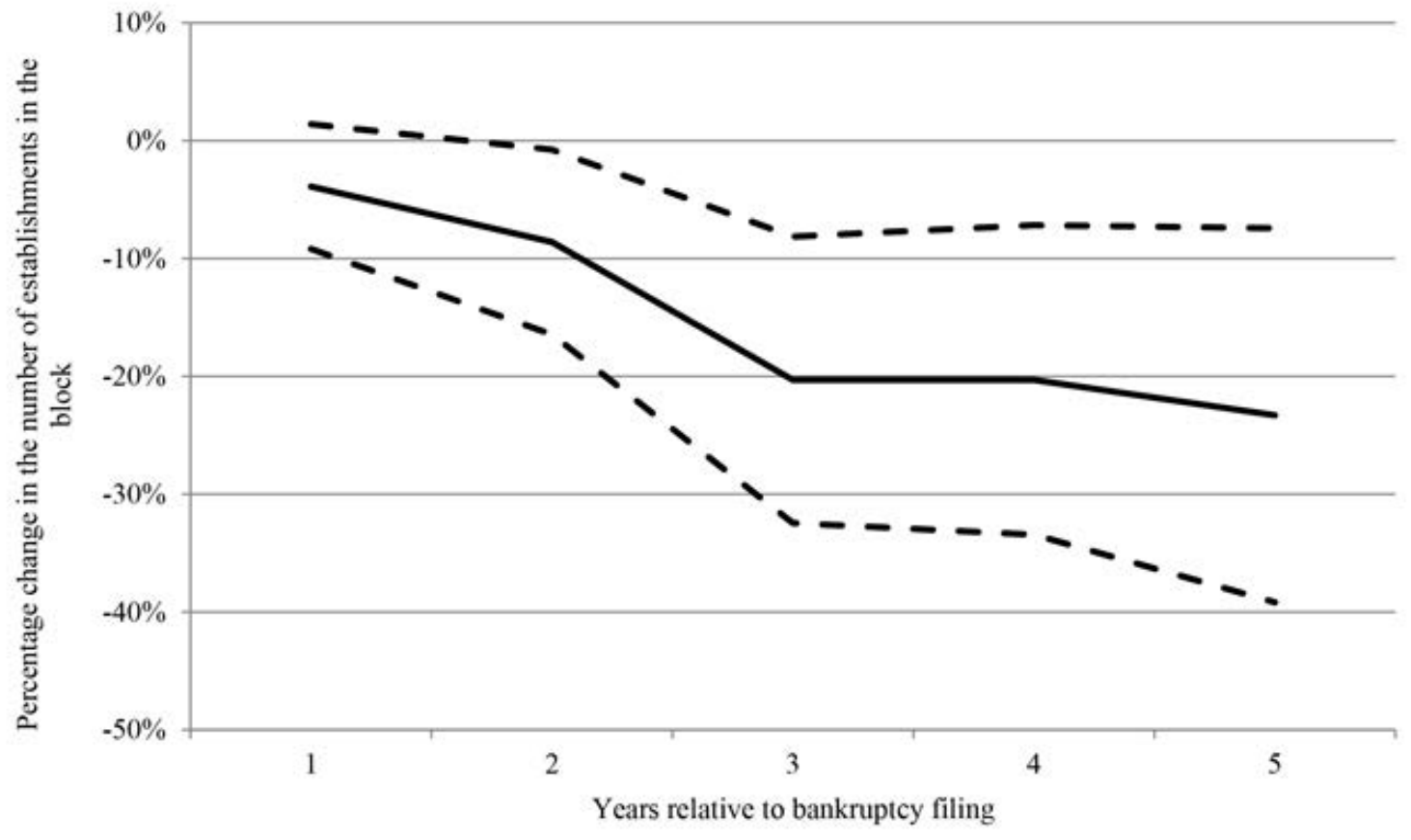




\section{Table I}

Summary Statistics

This table provides summary statistics for the bankrupt firms, their establishments, and non-bankrupt establishments residing in the same Census block, Census block group, and Census tract, respectively, as the bankrupt establishments. Statistics are reported for all bankrupt firms and separately for firms that are liquidated (Chapter 7) and reorganized (Chapter 11). Observation counts are rounded to the nearest thousand due to the disclosure rules of the U.S. Census Bureau.

\begin{tabular}{|c|c|c|c|c|c|c|c|c|c|}
\hline & \multicolumn{3}{|c|}{ All } & \multicolumn{3}{|c|}{ Chapter 7 (Liquidation) } & \multicolumn{3}{|c|}{ Chapter 11 (Reorganization) } \\
\hline & $\mathrm{N}$ & Mean & Std. Dev. & $\mathrm{N}$ & Mean & Std. Dev. & $\mathrm{N}$ & Mean & Std. Dev. \\
\hline \multicolumn{10}{|l|}{ a. Bankrupt Establishments } \\
\hline Employees & 91,000 & 37.0 & 193.5 & 16,000 & 28.0 & 84.4 & 75,000 & 38.8 & 209.3 \\
\hline Payroll (000s) & 91,000 & 977 & 9,169 & 16,000 & 585 & 2,475 & 75,000 & 1,060 & 10,020 \\
\hline Payroll / Employees (000s) & 91,000 & 22.2 & 48.0 & 16,000 & 19.6 & 45.8 & 75,000 & 22.7 & 48.5 \\
\hline \multicolumn{10}{|l|}{ b. Bankrupt Firms } \\
\hline Employees & 20,000 & 220 & 2,249 & 8,000 & 72 & 385 & 12,000 & 309 & 2,828 \\
\hline Establishments & 20,000 & 6.1 & 48.3 & 8,000 & 2.7 & 21.8 & 12,000 & 8.1 & 58.7 \\
\hline \multicolumn{10}{|l|}{ c. Census Blocks } \\
\hline Employees & 91,000 & 1,105 & 2,521 & 16,000 & 926 & 2,327 & 75,000 & 1,143 & 2,558 \\
\hline Establishments & 91,000 & 55.5 & 104.9 & 16,000 & 50.6 & 98.7 & 75,000 & 56.5 & 106.2 \\
\hline Employees / Establishments & 91,000 & 18.9 & 42.5 & 16,000 & 16.1 & 32.6 & 75,000 & 19.5 & 44.3 \\
\hline \multicolumn{10}{|l|}{ d. Census Block Groups } \\
\hline Employees & 91,000 & 3,453 & 6,706 & 16,000 & 3,455 & 7,014 & 75,000 & 3,453 & 6,640 \\
\hline Establishments & 91,000 & 165.3 & 266.5 & 16,000 & 171.1 & 283.8 & 75,000 & 164.1 & 262.7 \\
\hline Employees / Establishments & 91,000 & 18.3 & 21.3 & 16,000 & 17.4 & 20.8 & 75,000 & 18.6 & 21.4 \\
\hline \multicolumn{10}{|l|}{ e. Census Tracts } \\
\hline Employees & 91,000 & 6,581 & 11,079 & 16,000 & 6,862 & 11,553 & 75,000 & 6,522 & 10.976 \\
\hline Establishments & 91,000 & 330.3 & 456.3 & 16,000 & 348.5 & 475.1 & 75,000 & 326.5 & 452.2 \\
\hline Employees / Establishments & 91,000 & 17.8 & 14.6 & 16,000 & 17.3 & 14.3 & 75,000 & 17.9 & 14.7 \\
\hline
\end{tabular}




\section{Table II \\ First Stage}

This table reports estimates from the first-stage regression. The dependent variable, liquidation, is a dummy variable that indicates whether the establishment belongs to a company whose bankruptcy filing is converted from Chapter 11 reorganization to Chapter 7 liquidation. Share of cases converted is the share of all other Chapter 11 cases that a judge converted to Chapter 7. The controls are self-explanatory. All regressions include division by year fixed effects. The regression in column (3) further includes 2-digit NAICS industry fixed effects and a dummy indicating whether other related firms (e.g., subsidiaries of the same firm) also filed for bankruptcy at the same time. The sample includes all establishments belonging to companies that filed for Chapter 11 bankruptcy between 1992 and 2005. Standard errors, clustered at the division-by-year level, are reported in parentheses. ${ }^{*},{ }^{* *}$, and ${ }^{* * *}$ denotes statistical significance at the $10 \%, 5 \%$, and $1 \%$ level, respectively.

\begin{tabular}{llll}
\hline Dependent variable: & \multicolumn{3}{l}{ Liquidation } \\
\cline { 2 - 4 } & $(1)$ & $(2)$ & $(3)$ \\
\hline Share of cases converted & $0.578^{* * *}$ & $0.589^{* * *}$ & $0.588^{* * *}$ \\
& $(0.066)$ & $(0.066)$ & $(0.066)$ \\
a. Firm-level controls & & & \\
$\log ($ employees of bankrupt firm) & $-0.032^{* * *}$ & $-0.029^{* * *}$ \\
& & $(0.004)$ & $(0.004)$ \\
$\log ($ establishments of bankrupt firm) & -0.008 & $-0.016^{* * *}$ \\
& & $(0.005)$ & $(0.006)$ \\
b. Establishment-level control & & \\
$\log ($ employees of bankrupt establishment) & & $0.012^{* * *}$ & $0.010^{* * *}$ \\
& & $(0.003)$ & $(0.003)$ \\
c. Block-level control & & \\
$\log ($ employees at block of bankrupt establishment) & & $-0.027^{* * *}$ & $-0.026^{* * *}$ \\
& & $(0.002)$ & $(0.002)$ \\
\hline Division-year Fixed Effects & Yes & Yes & Yes \\
Industry Fixed Effects & No & No & Yes \\
F-stat for instrument & 75.73 & 79.34 & 80.01 \\
Adjusted R-squared & 0.140 & 0.164 & 0.173 \\
Observations & 91,000 & 91,000 & 91,000 \\
\hline
\end{tabular}




\section{Table III}

\section{Randomization}

This table reports randomization tests to illustrate the random assignment of bankruptcy judges within a division. The dependent variable, share of cases converted, is the share of all Chapter 11 cases that a judge converted to Chapter 7, excluding the current case. The right-hand side variables are self-explanatory. All regressions include division by year fixed effects. The regressions in columns (2)-(5) further include 2-digit NAICS industry fixed effects and a dummy indicating whether other related firms (e.g., subsidiaries of the same firm) also filed for bankruptcy at the same time. The sample includes all establishments belonging to companies that filed for Chapter 11 bankruptcy between 1992 and 2005. Standard errors, clustered at the division-by-year level, are reported in parentheses. ${ }^{*},{ }^{* *}$, and ${ }^{* * *}$ denotes statistical significance at the $10 \%$, $5 \%$, and $1 \%$ level, respectively.

\begin{tabular}{|c|c|c|c|c|c|}
\hline \multirow[t]{2}{*}{ Dependent variable: } & \multicolumn{5}{|c|}{ Share of cases converted } \\
\hline & $(1)$ & $(2)$ & $(3)$ & $(4)$ & $(5)$ \\
\hline \multicolumn{6}{|l|}{ a. Firm-level controls } \\
\hline $\log ($ employees of bankrupt firm) & & $\begin{array}{l}0.0009 \\
(0.001)\end{array}$ & $\begin{array}{l}0.0009 \\
(0.001)\end{array}$ & $\begin{array}{l}0.0009 \\
(0.001)\end{array}$ & $\begin{array}{l}0.0009 \\
(0.001)\end{array}$ \\
\hline $\log ($ establishments of bankrupt firm) & & $\begin{array}{c}-0.0015 \\
(0.001)\end{array}$ & $\begin{array}{c}-0.0015 \\
(0.001)\end{array}$ & $\begin{array}{c}-0.0014 \\
(0.001)\end{array}$ & $\begin{array}{c}-0.0015 \\
(0.001)\end{array}$ \\
\hline \multicolumn{6}{|l|}{ b. Establishment-level control } \\
\hline $\log ($ employees of bankrupt establishment) & & $\begin{array}{c}-0.0001 \\
(0.001)\end{array}$ & $\begin{array}{c}-0.0001 \\
(0.001)\end{array}$ & $\begin{array}{c}-0.0001 \\
(0.001)\end{array}$ & $\begin{array}{c}-0.0001 \\
(0.001)\end{array}$ \\
\hline \multicolumn{6}{|l|}{ c. Block-level control } \\
\hline $\log ($ employees at block of bankrupt establishment) & & $\begin{array}{l}0.0000 \\
(0.000)\end{array}$ & $\begin{array}{l}0.0000 \\
(0.000)\end{array}$ & $\begin{array}{l}0.0000 \\
(0.000)\end{array}$ & $\begin{array}{l}0.0000 \\
(0.000)\end{array}$ \\
\hline \\
\hline$\%$ change in employment (block level) & & & $\begin{array}{c}-0.0000 \\
(0.000)\end{array}$ & & $\begin{array}{c}-0.0000 \\
(0.000)\end{array}$ \\
\hline$\%$ change in employment (block-group level) & & & $\begin{array}{l}0.0003 \\
(0.000)\end{array}$ & & $\begin{array}{l}0.0003 \\
(0.000)\end{array}$ \\
\hline$\%$ change in employment (tract level) & & & $\begin{array}{l}0.0001 \\
(0.001)\end{array}$ & & $\begin{array}{l}0.0000 \\
(0.001)\end{array}$ \\
\hline e. Block composition & & & & & \\
\hline$\%$ employment in non-tradable & & & & $\begin{array}{l}0.0002 \\
(0.002)\end{array}$ & $\begin{array}{l}0.0002 \\
(0.002)\end{array}$ \\
\hline$\%$ employment in tradable & & & & $\begin{array}{l}0.0015 \\
(0.002) \\
\end{array}$ & $\begin{array}{l}0.0015 \\
(0.002) \\
\end{array}$ \\
\hline Division-year Fixed Effects & Yes & Yes & Yes & Yes & Yes \\
\hline Industry Fixed Effects & No & Yes & Yes & Yes & Yes \\
\hline F-test for joint significance of industry $\mathrm{FE}$ & - & 0.439 & 0.438 & 0.442 & 0.442 \\
\hline Adjusted R-squared & 0.777 & 0.777 & 0.777 & 0.777 & 0.777 \\
\hline Observations & 91,000 & 91,000 & 91,000 & 91,000 & 91,000 \\
\hline
\end{tabular}




\section{Table IV \\ Main Results}

In columns (1)-(2), the dependent variable is the annualized percentage change in employment in the Census block of the bankrupt establishment (excluding employment of the bankrupt establishment) in the five years following the bankruptcy filing. The dependent variable in columns (3)-(4) is defined similarly with respect to the number of establishments. Liquidation is a dummy variable that indicates whether the establishment belongs to a company whose case is converted from Chapter 11 reorganization to Chapter 7 liquidation. The regressions in columns (1) and (3) are estimated by OLS; the regressions in columns (2) and (4) are estimated by 2SLS using as instrument the share of cases converted. All regressions contain the full set of controls used in column (2) of Table II. The sample includes all establishments belonging to companies that filed for Chapter 11 bankruptcy between 1992 and 2005. Standard errors, clustered at the division-by-year level, are reported in parentheses. ${ }^{*},{ }^{* *}$, and ${ }^{* * *}$ denotes statistical significance at the $10 \%, 5 \%$, and $1 \%$ level, respectively.

\begin{tabular}{llllll}
\hline Dependent variable: & \multicolumn{2}{c}{ Employment } & & \multicolumn{2}{c}{ Establishments } \\
\cline { 2 - 3 } \cline { 6 - 7 } Model & OLS & IV-2SLS & & OLS & IV-2SLS \\
& $(1)$ & $(2)$ & & $(3)$ & $(4)$ \\
\hline Liquidation & $-0.025^{* * *}$ & $-0.040^{* *}$ & & $-0.037^{* * *}$ & $-0.047^{* * *}$ \\
& $(0.002)$ & $(0.017)$ & & $(0.002)$ & $(0.016)$ \\
\hline Control variables & Yes & Yes & & Yes & Yes \\
Division-year Fixed Effects & Yes & Yes & & Yes & Yes \\
Industry Fixed Effects & Yes & Yes & & Yes & Yes \\
Adjusted R-squared & 0.154 & 0.190 & & 0.322 & 0.162 \\
Observations & 91,000 & 91,000 & & 91,000 & 91,000 \\
\hline
\end{tabular}




\section{Table V \\ Decomposition}

The regressions in Panel A are variants of the regression in column (2) of Table IV, which is reproduced in column (1). Columns (2) and (3) decompose the change in employment into i) employment changes from existing establishments, and ii) employment changes from new establishments. Similarly, Panel B contains regressions that are are variants of the regression in column (4) of Table IV, with columns (2) and (3) decomposing the number of establishments into i) the number of establishment closures ("deaths") and ii) the number of establishment openings ("births"). The sample includes all establishments belonging to companies that filed for Chapter 11 bankruptcy between 1992 and 2005. Standard errors, clustered at the division-by-year level, are reported in parentheses. ${ }^{*},{ }^{* *}$, and ${ }^{* * *}$ denotes statistical significance at the $10 \%$, $5 \%$, and $1 \%$ level, respectively.

Panel A: Change in Employment

\begin{tabular}{|c|c|c|c|}
\hline \multirow[t]{2}{*}{ Dependent variable: } & \multicolumn{3}{|c|}{ Employment } \\
\hline & $\begin{array}{l}\text { All } \\
\text { Establishments } \\
\text { (1) }\end{array}$ & $\begin{array}{l}\text { Existing } \\
\text { Establishments } \\
(2) \\
\end{array}$ & $\begin{array}{l}\text { New } \\
\text { Establishments } \\
(3)\end{array}$ \\
\hline Liquidation & $\begin{array}{l}-0.040^{* *} \\
(0.017)\end{array}$ & $\begin{array}{l}-0.030^{* *} \\
(0.014)\end{array}$ & $\begin{array}{l}-0.010 \\
(0.010)\end{array}$ \\
\hline $\begin{array}{l}\text { Control variables } \\
\text { Division-year Fixed Effects } \\
\text { Industry Fixed Effects } \\
\text { Model } \\
\text { Adjusted R-squared } \\
\text { Observations }\end{array}$ & $\begin{array}{l}\text { Yes } \\
\text { Yes } \\
\text { Yes } \\
\text { IV-2SLS } \\
0.190 \\
91,000\end{array}$ & $\begin{array}{l}\text { Yes } \\
\text { Yes } \\
\text { Yes } \\
\text { IV-2SLS } \\
0.025 \\
91,000\end{array}$ & $\begin{array}{l}\text { Yes } \\
\text { Yes } \\
\text { Yes } \\
\text { IV-2SLS } \\
0.012 \\
91,000\end{array}$ \\
\hline \multicolumn{4}{|c|}{ Panel B: Change in Number of Establishments } \\
\hline \multirow[t]{2}{*}{ Dependent variable: } & \multicolumn{3}{|c|}{ Establishments } \\
\hline & $\begin{array}{l}\text { All } \\
\text { Establishments } \\
(1)\end{array}$ & $\begin{array}{l}\text { Existing } \\
\text { Establishments } \\
(2)\end{array}$ & $\begin{array}{l}\text { New } \\
\text { Establishments } \\
(3)\end{array}$ \\
\hline Liquidation & $\begin{array}{l}-0.047^{* * *} \\
(0.016)\end{array}$ & $\begin{array}{l}-0.046^{* * *} \\
(0.012)\end{array}$ & $\begin{array}{l}-0.002 \\
(0.010) \\
\end{array}$ \\
\hline Control variables & Yes & Yes & Yes \\
\hline Division-year Fixed Effects & Yes & Yes & Yes \\
\hline Industry Fixed Effects & Yes & Yes & Yes \\
\hline Model & IV-2SLS & IV-2SLS & IV-2SLS \\
\hline Adjusted R-squared & 0.162 & 0.129 & 0.061 \\
\hline Observations & 91,000 & 91,000 & 91,000 \\
\hline
\end{tabular}




\section{Table VI \\ Geographies}

The regressions in Panel A are variants of the regression in column (2) of Table IV, which is reproduced in column (1). In columns (2) and (3), changes in employment are computed for the Census block group and Census tract, respectively. The regressions in columns (4) and (5) are analogous except that employment in the Census block group (and Census tract, respectively) is net of employment in the Census block of the bankrupt establishment. The regressions in Panels B and $\mathrm{C}$ are analogous, except that the change in employment is decomposed into i) employment changes from existing establishments, and ii) employment changes from new establishments. The sample includes all establishments belonging to companies that filed for Chapter 11 bankruptcy between 1992 and 2005. Standard errors, clustered at the division-by-year level, are reported in parentheses. ${ }^{*}, * *$, and ${ }^{* * *}$ denotes statistical significance at the $10 \%, 5 \%$, and $1 \%$ level, respectively.

Panel A: Overall Effect

\begin{tabular}{|c|c|c|c|c|c|}
\hline \multirow{2}{*}{$\begin{array}{l}\text { Dependent variable } \\
\text { Geography }\end{array}$} & \multicolumn{3}{|c|}{ Employment } & \multicolumn{2}{|c|}{$\begin{array}{l}\text { Employment net of block } \\
\text { of bankrupt establishment }\end{array}$} \\
\hline & $\begin{array}{l}\text { Blocks } \\
(1)\end{array}$ & $\begin{array}{l}\text { Block-groups } \\
(2)\end{array}$ & $\begin{array}{l}\text { Tracts } \\
(3)\end{array}$ & $\begin{array}{l}\text { Block-groups } \\
(4)\end{array}$ & $\begin{array}{l}\text { Tracts } \\
(5)\end{array}$ \\
\hline Liquidation & $\begin{array}{l}-0.040^{* *} \\
(0.017)\end{array}$ & $\begin{array}{l}-0.017 \\
(0.010)\end{array}$ & $\begin{array}{l}0.001 \\
(0.007)\end{array}$ & $\begin{array}{l}-0.006 \\
(0.014)\end{array}$ & $\begin{array}{l}0.005 \\
(0.008)\end{array}$ \\
\hline Control variables & Yes & Yes & Yes & Yes & Yes \\
\hline Division-year Fixed Effects & Yes & Yes & Yes & Yes & Yes \\
\hline Industry Fixed Effects & Yes & Yes & Yes & Yes & Yes \\
\hline Observations & 91,000 & 91,000 & 91,000 & 91,000 & 91,000 \\
\hline \multicolumn{6}{|c|}{ Panel B: Existing Establishments } \\
\hline Dependent variable & \multicolumn{3}{|c|}{ Employment } & \multicolumn{2}{|c|}{$\begin{array}{l}\text { Employment net of block } \\
\text { of bankrupt establishment }\end{array}$} \\
\hline Geography & $\begin{array}{l}\text { Blocks } \\
(1)\end{array}$ & $\begin{array}{l}\text { Block-groups } \\
(2)\end{array}$ & $\begin{array}{l}\text { Tracts } \\
(3)\end{array}$ & $\begin{array}{l}\text { Block-groups } \\
(4)\end{array}$ & $\begin{array}{l}\text { Tracts } \\
(5)\end{array}$ \\
\hline Liquidation & $\begin{array}{l}-0.030^{* *} \\
(0.014)\end{array}$ & $\begin{array}{l}-0.008 \\
(0.010)\end{array}$ & $\begin{array}{l}0.008 \\
(0.007)\end{array}$ & $\begin{array}{l}0.003 \\
(0.014)\end{array}$ & $\begin{array}{l}0.007 \\
(0.008)\end{array}$ \\
\hline Control variables & Yes & Yes & Yes & Yes & Yes \\
\hline Division-year Fixed Effects & Yes & Yes & Yes & Yes & Yes \\
\hline Industry Fixed Effects & Yes & Yes & Yes & Yes & Yes \\
\hline Observations & 91,000 & 91,000 & 91,000 & 91,000 & 91,000 \\
\hline \multicolumn{6}{|c|}{ Panel C: New Establishments } \\
\hline Dependent variable & \multicolumn{3}{|c|}{ Employment } & \multicolumn{2}{|c|}{$\begin{array}{l}\text { Employment net of block } \\
\text { of bankrupt establishment }\end{array}$} \\
\hline Geography & $\begin{array}{l}\text { Blocks } \\
(1)\end{array}$ & $\begin{array}{l}\text { Block-groups } \\
(2)\end{array}$ & $\begin{array}{l}\text { Tracts } \\
(3)\end{array}$ & $\begin{array}{l}\text { Block-groups } \\
(4)\end{array}$ & $\begin{array}{l}\text { Tracts } \\
(5)\end{array}$ \\
\hline Liquidation & $\begin{array}{c}-0.010 \\
(0.010) \\
\end{array}$ & $\begin{array}{l}-0.009 \\
(0.007)\end{array}$ & $\begin{array}{l}-0.007 \\
(0.006)\end{array}$ & $\begin{array}{l}-0.009 \\
(0.008) \\
\end{array}$ & $\begin{array}{l}-0.002 \\
(0.005)\end{array}$ \\
\hline Control variables & Yes & Yes & Yes & Yes & Yes \\
\hline Division-year Fixed Effects & Yes & Yes & Yes & Yes & Yes \\
\hline Industry Fixed Effects & Yes & Yes & Yes & Yes & Yes \\
\hline Observations & 91,000 & 91,000 & 91,000 & 91,000 & 91,000 \\
\hline
\end{tabular}




\section{Table VII}

\section{Industry Sectors}

This table presents variants of the regression in column (2) of Table IV, except that the dependent variable is employment in non-tradable industries (Panel A), services (Panel B) and tradable industries (Panel C). In each panel, column (1) considers all bankruptcies, whereas columns (2)-(4) only consider bankruptcies in the non-tradable sector, services, and the tradable sector, respectively. Standard errors, clustered at the division-by-year level, are reported in parentheses. ${ }^{*},{ }^{* *}$, and ${ }^{* * *}$ denotes statistical significance at the $10 \%$, $5 \%$, and $1 \%$ level, respectively.

\section{Panel A: Non-tradable Industries}

\begin{tabular}{lllll}
\hline Dependent variable: & \multicolumn{4}{c}{ Employment in non-tradable industries } \\
\cline { 2 - 5 } Treatment & All & Non-tradable & Services & Tradable \\
& $(1)$ & $(2)$ & $(3)$ & $(4)$ \\
\hline Liquidation & $-0.014^{*}$ & $-0.040^{* *}$ & -0.007 & -0.013 \\
& $(0.008)$ & $(0.020)$ & $(0.013)$ & $(0.010)$ \\
\hline Control variables & Yes & Yes & Yes & Yes \\
Division-year Fixed Effects & Yes & Yes & Yes & Yes \\
Industry Fixed Effects & Yes & Yes & Yes & Yes \\
Model & IV-2SLS & IV-2SLS & IV-2SLS & IV-2SLS \\
First stage F-test & 81.59 & 19.48 & 39.20 & 49.20 \\
Observations & 91,000 & 47,000 & 32,000 & 12,000 \\
\hline
\end{tabular}

Panel B: Services

\begin{tabular}{lllll}
\hline \multirow{2}{*}{$\begin{array}{l}\text { Dependent variable: } \\
\text { Treatment }\end{array}$} & \multicolumn{4}{c}{ Employment in services industries } \\
\cline { 2 - 5 } & $(1)$ & $\begin{array}{l}\text { Non-tradable } \\
(2)\end{array}$ & $\begin{array}{l}\text { Services } \\
(3)\end{array}$ & $\begin{array}{l}\text { Tradable } \\
(4)\end{array}$ \\
\hline Liquidation & $-0.029^{* *}$ & $-0.045^{*}$ & $-0.050^{* *}$ & -0.011 \\
& $(0.012)$ & $(0.025)$ & $(0.023)$ & $(0.017)$ \\
\hline Control variables & Yes & Yes & Yes & Yes \\
Division-year Fixed Effects & Yes & Yes & Yes & Yes \\
Industry Fixed Effects & Yes & Yes & Yes & Yes \\
Model & IV-2SLS & IV-2SLS & IV-2SLS & IV-2SLS \\
First stage F-test & 81.59 & 19.48 & 39.20 & 49.20 \\
Observations & 91,000 & 47,000 & 32,000 & 12,000 \\
\hline \multirow{5}{*}{ Panel C: Tradable Industries } & \\
\hline Dependent variable: & \multicolumn{2}{c}{ Employment in tradable industries } \\
\cline { 2 - 6 } Treatment & All & Non-tradable & Services & Tradable \\
& $(1)$ & $(2)$ & $(3)$ & $(4)$ \\
\hline Liquidation & 0.003 & -0.007 & -0.003 & 0.002 \\
& $(0.009)$ & $(0.016)$ & $(0.012)$ & $(0.017)$ \\
\hline Control variables & Yes & Yes & Yes & Yes \\
Division-year Fixed Effects & Yes & Yes & Yes & Yes \\
Industry Fixed Effects & Yes & Yes & Yes & Yes \\
Model & IV-2SLS & IV-2SLS & IV-2SLS & IV-2SLS \\
First stage F-test & 81.59 & 19.48 & 39.20 & 49.20 \\
Observations & 91,000 & 47,000 & 32,000 & 12,000 \\
\hline
\end{tabular}




\section{Table VIII}

Fate of the Bankrupt Establishments

This table presents estimates from regressions of the annualized change in employment in the block of the bankrupt establishment (excluding employment of the bankrupt establishment) in the five years following the bankruptcy filing on a set of dummy variables that capture the "fate" of the bankrupt establishment. Continuer indicates whether the establishment remains in its current operations. Reallocated in same 2digit NAICS indicates whether the establishment is reallocated to the same 2-digit NAICS industry. The other reallocation indicators are defined analogously. Vacant indicates whether the establishment stays vacant throughout the 5-year period. In columns (7)-(8), vacant is the base group. The sample includes all establishments belonging to companies that filed for Chapter 11 bankruptcy between 1992 and 2005. Standard errors, clustered at the division-by-year level, are reported in parentheses. *, **, and *** denotes statistical significance at the 10\%,5\%, and $1 \%$ level, respectively.

\begin{tabular}{|c|c|c|c|c|c|c|c|c|}
\hline \multirow[t]{2}{*}{ Dependent variable: } & \multicolumn{8}{|c|}{ Employment } \\
\hline & $(1)$ & $(2)$ & $(3)$ & $(4)$ & $(5)$ & $(6)$ & $(7)$ & (8) \\
\hline Continuer & $\begin{array}{l}0.072^{\text {*** }} \\
(0.003)\end{array}$ & & & & & & $\begin{array}{l}0.071^{* * *} \\
(0.003)\end{array}$ & $\begin{array}{l}0.071^{* * *} \\
(0.003)\end{array}$ \\
\hline Reallocated in same 2-digit NAICS & & $\begin{array}{l}-0.005^{* *} \\
(0.002)\end{array}$ & & & & & $\begin{array}{l}0.012^{* * *} \\
(0.002)\end{array}$ & \\
\hline Reallocated in different 2-digit NAICS & & & $\begin{array}{l}-0.035^{* * *} \\
(0.002)\end{array}$ & & & & $\begin{array}{l}-0.010^{* * *} \\
(0.002)\end{array}$ & \\
\hline Reallocated in same 3-digit NAICS & & & & $\begin{array}{l}-0.001 \\
(0.002)\end{array}$ & & & & $\begin{array}{l}0.015^{* * *} \\
(0.002)\end{array}$ \\
\hline Reallocated in different 3-digit NAICS & & & & & $\begin{array}{l}-0.036^{* * *} \\
(0.002)\end{array}$ & & & $\begin{array}{l}-0.009^{* * *} \\
(0.002)\end{array}$ \\
\hline Vacant & & & & & & $\begin{array}{l}-0.023^{* * *} \\
(0.002) \\
\end{array}$ & & \\
\hline Control variables & Yes & Yes & Yes & Yes & Yes & Yes & Yes & Yes \\
\hline Division-year Fixed Effects & Yes & Yes & Yes & Yes & Yes & Yes & Yes & Yes \\
\hline Industry Fixed Effects & Yes & Yes & Yes & Yes & Yes & Yes & Yes & Yes \\
\hline Model & OLS & OLS & OLS & OLS & OLS & OLS & OLS & OLS \\
\hline Adjusted R-squared & 0.341 & 0.274 & 0.291 & 0.273 & 0.293 & 0.282 & 0.344 & 0.345 \\
\hline Observations & 91,000 & 91,000 & 91,000 & 91,000 & 91,000 & 91,000 & 91,000 & 91,000 \\
\hline
\end{tabular}

